Article

\title{
Ocean Response to Successive Typhoons Sarika and Haima (2016) Based on Data Acquired via Multiple Satellites and Moored Array
}

\author{
Han Zhang 1,2®, Xiaohui Liu 1,2,*, Renhao $\mathrm{Wu}^{2,3}$, Fu Liu ${ }^{1,4}$, Linghui Yu ${ }^{5}$, Xiaodong Shang ${ }^{5}$, \\ Yongfeng Qi ${ }^{5}$, Yuan Wang ${ }^{1}$, Xunshu Song ${ }^{1}$, Xiaohui Xie ${ }^{1}$, Chenghao Yang ${ }^{1}$, Di Tian ${ }^{1}$ and \\ Wenyan Zhang ${ }^{6}$ (D) \\ 1 State Key Laboratory of Satellite Ocean Environment Dynamics, Second Institute of Oceanography, \\ Ministry of Natural Resources, Hangzhou 310012, China; zhanghan@sio.org.cn (H.Z.); \\ liufu@sio.org.cn (F.L.); wangyuan@sio.org.cn (Y.W.); songxs@sio.org.cn (X.S.); xxie@sio.org.cn (X.X.); \\ yangch1101@sio.org.cn (C.Y.); tiandi@sio.org.cn (D.T.) \\ 2 Southern Marine Science and Engineering Guangdong Laboratory (Zhuhai), Zhuhai 519082, China; \\ wurenhao@mail.sysu.edu.cn \\ 3 Guangdong Province Key Laboratory for Climate Change and Natural Disaster Studies, and School of \\ Atmospheric Sciences, Sun Yat-sen University, Zhuhai 519082, China \\ 4 Key Laboratory of Mesoscale Severe Weather/MOE and School of Atmospheric Sciences, Nanjing University, \\ Nanjing 210023, China \\ 5 State Key Laboratory of Tropical Oceanography, South China Sea Institute of Oceanology, \\ Chinese Academy of Sciences, Guangzhou 510301, China; lhyu@scsio.ac.cn (L.Y.); \\ xdshang@scsio.ac.cn (X.S.); yfqi@scsio.ac.cn (Y.Q.) \\ 6 Institute of Coastal Research, Helmholtz-Zentrum Geesthacht, 21502 Geesthacht, Germany; \\ wenyan.zhang@hzg.de \\ * Correspondence: xh_liu@sio.org.cn
}

Received: 25 August 2019; Accepted: 9 October 2019; Published: 11 October 2019

\begin{abstract}
Tropical cyclones (TCs) are natural disasters for coastal regions. TCs with maximum wind speeds higher than $32.7 \mathrm{~m} / \mathrm{s}$ in the north-western Pacific are referred to as typhoons. Typhoons Sarika and Haima successively passed our moored observation array in the northern South China Sea in 2016. Based on the satellite data, the winds (clouds and rainfall) biased to the right (left) sides of the typhoon tracks. Sarika and Haima cooled the sea surface $\sim 4$ and $\sim 2{ }^{\circ} \mathrm{C}$ and increased the salinity $\sim 1.2$ and $\sim 0.6 \mathrm{psu}$, respectively. The maximum sea surface cooling occurred nearly one day after the two typhoons. Station 2 (S2) was on left side of Sarika's track and right side of Haima's track, which is studied because its data was complete. Strong near-inertial currents from the ocean surface toward the bottom were generated at $\mathrm{S} 2$, with a maximum mixed-layer speed of $\sim 80 \mathrm{~cm} / \mathrm{s}$. The current spectrum also shows weak signal at twice the inertial frequency $(2 f)$. Sarika deepened the mixed layer, cooled the sea surface, but warmed the subsurface by $\sim 1{ }^{\circ} \mathrm{C}$. Haima subsequently pushed the subsurface warming anomaly into deeper ocean, causing a temperature increase of $\sim 1.8^{\circ} \mathrm{C}$ therein. Sarika and Haima successively increased the heat content anomaly upper than $160 \mathrm{~m}$ at $\mathrm{S} 2$ to $\sim 50$ and $\sim 100 \mathrm{~m}^{\circ} \mathrm{C}$, respectively. Model simulation of the two typhoons shows that mixing and horizontal advection caused surface ocean cooling, mixing and downwelling caused subsurface warming, while downwelling warmed the deeper ocean. It indicates that Sarika and Haima sequentially modulated warm water into deeper ocean and influenced internal ocean heat budget. Upper ocean salinity response was similar to temperature, except that rainfall refreshed sea surface and caused a successive salinity decrease of $\sim 0.03$ and $\sim 0.1$ psu during the two typhoons, changing the positive subsurface salinity anomaly to negative
\end{abstract}

Keywords: ocean response; tropical cyclone; typhoon; temperature anomaly; salinity anomaly; wind speed; sea surface; mixed layer; South China Sea 


\section{Introduction}

Tropical cyclones (TCs) are intense natural hazards that pose a significant threat to coastal and inland areas. In the regions around the Northwest Pacific, TCs with maximum wind speeds greater than $32.7 \mathrm{~m} / \mathrm{s}$ are usually referred to as typhoons. The response of ocean to a tropical cyclone is dramatic and not only impacts the local ocean environment [1-4], global ocean heat transport [5-7], and kinetic energy budget [8-10], but also changes the development of the tropical cyclone itself through TC-ocean feedbacks [11-14]. The response is indeed a hot topic in the study of the atmosphere and oceans.

The strong wind stress of a tropical cyclone induces a significant near-inertial horizontal current [15-19]. The near-inertial current normally decays within 5-20 inertial periods and propagates both horizontally and vertically in the ocean $[20,21]$. The near-inertial current is accompanied by alternative upwelling and downwelling (near-inertial pumping) [22], which is asymmetric with a rapid transition from a maximum in the downwelling phase to a maximum in the upwelling phase, followed by a gradual transition to the next downwelling maximum [23,24]. The horizontal and vertical propagation of the near-inertial current results in wave dispersion and propagation of kinetic energy $[10,16,25,26]$, which can also generate super-inertial internal waves such as double-inertial frequency $(2 f)$ waves $[27,28]$ that contribute to the energy cascade toward dissipation. In the Northern (or Southern) Hemispheres, the upper ocean current responses to a tropical cyclone are respectively biased to the left and right sides of the TC track, owing to the better wind-current resonance on the right (or left) sides [29,30].

The TC-induced near-inertial current enhances the velocity shear in the mixed layer [31], deepens the mixed layer, cools sea surface, and warms subsurface [6,7]. The sea surface temperature (SST) cooling was usually by $1-6^{\circ} \mathrm{C}[2,4,31-35]$, and by more than $10^{\circ} \mathrm{C}$ in some extreme cases [36,37]. Owing to the rightward (or leftward) bias of the current response, the temperature response is also usually biased to the right side (or left side) of the TC track in the Northern (or Southern) Hemisphere [15,22]. Besides mixing, the vertical advection (upwelling and downwelling) and horizontal advection can also modulate the oceanic temperature structure. In general, the subsurface warm anomaly can be strengthened or weakened by upwelling or downwelling $[15,22,38]$, and the effect of horizontal advection depends on the current speed and horizontal temperature gradient [22]. The vertical advection mainly influences the subsurface and deeper ocean, as Argo data reveal that upwelling contributes an average of $15 \%$ of the cooling in the near-surface layer $(10-30 \mathrm{~m}), 84 \%$ in the subsurface layer $(30-250 \mathrm{~m})$, and $94 \%$ in the deep layer $(250-600 \mathrm{~m})$ during the period of $0.5-2.5$ days after the passage of a typhoon [39]. The ocean temperature response to TCs contributes not only to the local ocean environment, but also to the global meridional heat transport [6,7]. Studies show that TCs are responsible for $1.87 \mathrm{PW}\left(11.05 \mathrm{~W} / \mathrm{m}^{2}\right)$ of the annual global heat transfer from the ocean to atmosphere [40]. The response of ocean salinity to a TC is similar to the temperature response [41,42], except for the sea surface salinity decrease by precipitation [42]. In general, most observations have revealed positive and negative sea surface salinity anomalies on the right and left sides of TC tracks in the Northern Hemisphere [41,43-45].

Although the oceanic response to a tropical cyclone was widely studied in the past decades, there are still many aspects that are waiting for further study. For example, the ocean response to sequential tropical cyclones was seldom studied before. Some previous observation shows that the second TC usually cools the ocean surface cold wake of a preceding TC $[46,47]$ and tends to be weakened as it travels over the cold wake of the first TC $[47,48]$, but further study was in a shortage because of the limited amount of in situ observation. In 2016, our moored observation array in the northern South China Sea captured two successively passing TCs, Sarika and Haima, over a period of four days. Combined with remote sensing data, the observations provided a good opportunity to study oceanic response to successive TCs. We will show how Sarika and Haima influenced the local 
ocean current, temperature, and salinity, and particularly decomposed the inner ocean mechanisms that modulated the upper ocean temperature using a three dimensional model, then summarize with a sketch how the temperature profiles were changed successively by the two TCs. Hopefully the result of this paper will help us to better understand the TC-ocean interaction, especially the upper ocean thermal response to sequential tropical cyclones.

\section{Data and Method}

\subsection{Remote Sensing Data Acquired via Multiple Satellites}

The 1 hourly cloud-top brightness temperature data with $0.05^{\circ} \times 0.05^{\circ}$ horizontal resolution used in this study was acquired by the Himawari-8 satellite that downloaded from the website of Kochi University. The 6 hourly surface wind data with $0.25^{\circ} \times 0.25^{\circ}$ horizontal resolution was acquired using the cross-calibrated multi-platform (CCMP) version 2.0 ocean vector wind analysis system [49]. The 3 hourly rainfall data with $0.25^{\circ} \times 0.25^{\circ}$ horizontal resolution was obtained through the CPC MORPHing technique (CMORPH) [50] by the National Oceanic and Atmospheric Administration. The data of the daily sea surface height anomalies and geostrophic velocity anomalies with $0.25^{\circ} \times 0.25^{\circ}$ horizontal resolution were obtained from the Ssalto/Duacs altimeter products that were produced and distributed by the Copernicus Marine and Environment Monitoring Service (CMEMS). The daily sea surface temperature data with $0.088^{\circ} \times 0.088^{\circ}$ horizontal resolution consisted of optimally interpolated (OI) microwave sea surface temperature (SST) data [51]. The eight-day running average Level 3 sea surface salinity data with $0.25^{\circ} \times 0.25^{\circ}$ horizontal resolution was obtained using RSS soil moisture active passive (SMAP) sea surface salinity analysis [52]. See Table 1 for the sources (websites) of the data.

Table 1. Sources of Data *.

\begin{tabular}{|c|c|}
\hline Data & Website \\
\hline Cloud-top brightness temperature & http://weather.is.kochi-u.ac.jp/sat/GAME/2016/Oct/IR1 \\
\hline Surface wind & http://www.remss.com/measurements/ccmp \\
\hline Rainfall & $\begin{array}{l}\text { https://www.cpc.ncep.noaa.gov/products/janowiak/ } \\
\text { cmorph_description.html }\end{array}$ \\
\hline Sea surface height anomaly, geostrophic velocity & http://marine.copernicus.eu \\
\hline Sea surface temperature & http://data.remss.com/SST/daily/mw_ir/v05.0/netcdf/2016 \\
\hline Sea surface salinity & $\begin{array}{c}\text { http://data.remss.com/smap/SSS/V04.0/FINAL/L3/8day_ } \\
\text { running/2016 }\end{array}$ \\
\hline JTWC best track data & http://www.usno.navy.mil/JTWC \\
\hline JMA best track data & $\begin{array}{l}\text { http://www.jma.go.jp/jma/jma-eng/jma-center/rsmc-hp- } \\
\text { pub-eg/besttrack.html }\end{array}$ \\
\hline CMA best track data & http://tcdata.typhoon.gov.cn \\
\hline
\end{tabular}

* JTWC, JMA and CMA correspond to the Joint Typhoon Warning Center of the UST, the Japan Meteorological Agency, and the China Meteorological Administration.

\subsection{Buoy and Mooring Stations}

In 2016, we set up three observation stations to monitor the tropical cyclones that passed by. Stations 1 and 2 (S1 and S2) contained buoys and moorings (B1 and M1; B2 and M2), while Station 3 (S3) contained only a buoy (B3). Tropical cyclone Sarika travelled through the observation array between October 16 and 18, and tropical cyclone Haima followed on the right side of the observation array between October 20 and 21. Unfortunately, Buoy 3 (B3) and Buoy 1 (B1) were damaged on August 5 and September 16, respectively. Hence, only Mooring 1 (M1), Buoy 2 (B2), and Mooring 2 (M2) were operational during the TCs. We mainly analyze the ocean response at Station 2 (B2 and M2, Tables 2 and 3) in the main body of this paper because its data was complete, and present the observation from M1 in Appendix A as a supplement. 
Table 2. Observation instruments and measured elements at Buoy 2 *.

\begin{tabular}{cccc}
\hline Instruments & $\begin{array}{c}\text { Measured } \\
\text { Elements }\end{array}$ & Designed Depth (m) & Resolution (s) \\
\hline Gill-MetPak & Meteorology & 4 m above from sea surface & $1(3600)$ \\
JFE-A7CT & $T, S$ & $12 \backslash 22 \backslash 52 \backslash 68.5 \backslash 90.5 \backslash 111 \backslash 131 \backslash 142 \backslash 162 \backslash 182 \backslash 202 \backslash 242 \backslash 282 \backslash 322 \backslash 362 \backslash 402 \backslash 442 \backslash 482$ & 300 \\
ONT7000 & $T$ & $17227.5 \backslash 44 \backslash 49.5 \backslash 63 \backslash 74 \backslash 85 \backslash 96 \backslash 106 \backslash 147 \backslash 157 \backslash 302 \backslash 342 \backslash 382 \backslash 422 \backslash 462 \backslash 502$ & 1 \\
SBE-56 & $T$ & $33 \backslash 38.5 \backslash 57.5 \backslash 79.5 \backslash 101 \backslash 116 \backslash 121 \backslash 126 \backslash 121 \backslash 126 \backslash 137 \backslash 152 \backslash 172 \backslash 192 \backslash 222 \backslash 262$ & 1 \\
RDI 75K-ADCP & $U, V$ & location: $133 \mathrm{~m}$, uplooking; first bin: $24.74 \mathrm{~m}$; last bin: $136.74 \mathrm{~m}$; bin & 300 \\
size: $16 \mathrm{~m}$ & & \\
RDI 300K-ADCP & $U, V$ & location: $1385 \mathrm{~m}$, uplooking; first bin: $15.69 \mathrm{~m}$; last bin: 255.69 ; bin size: & 600 \\
\hline
\end{tabular}

* Red font indicates that the instrument was lost during the observation, while blue font indicates no data or some error in data. The meteorological station (Gill-MetPak) observations occurred every second, with outputs every 3600 $\mathrm{s}$ for air temperature, pressure, wind, and dew temperature $4 \mathrm{~m}$ above the sea surface. $T, S, P, U$, and $V$ respectively denote temperature, salinity, pressure, eastward current speed, and northward current speed.

Table 3. Observation instruments and measured elements at Mooring 2 *.

\begin{tabular}{cccc}
\hline Instrument & $\begin{array}{c}\text { Measured } \\
\text { Element }\end{array}$ & Design Installation Depth (m) & Resolution (s) \\
\hline SBE-37 & $T, S, P$ & $300 / 315 / 330 / 345 / 360 / 375 / 400 / 450 / 500 / \mathrm{L} 160 / \mathrm{L} 140 / \mathrm{L} 120 / \mathrm{L} 100 / \mathrm{L} 80 / \mathrm{L} 60 / \mathrm{L} 40$ & 120 \\
SBE-39 & $T, P$ & $600 / 700 / 800$ & 120 \\
Seaguard & $U, V$ & $600 / 700 / 800 / \mathrm{L} 80$ & 600 \\
RDI 75K-ADCP & $U, V$ & Location: $500 \mathrm{~m}$, uplooking; first bin: $24.45 \mathrm{~m}$; last bin: $600.45 \mathrm{~m}$; bin & 600 \\
& & size: $16 \mathrm{~m}$ & 600 \\
RDI 75K-ADCP & $U, V$ & Location: $\mathrm{L} 80 \mathrm{~m}$, downlooking; first bin: $6.15 \mathrm{~m}$; last bin: $110.15 \mathrm{~m}$; bin & size: $4 \mathrm{~m}$ \\
\hline
\end{tabular}

${ }^{*} \mathrm{~L}$ indicates above ocean bottom; for example, L140 means $140 \mathrm{~m}$ above the ocean bottom. $T, S, P, U$, and $V$ denote temperature, salinity, pressure, eastward current speed, and northward current speed, respectively.

Buoy 2 was deployed at $114^{\circ} 54.42^{\prime} \mathrm{E}$ and $19^{\circ} 27.328^{\prime} \mathrm{N}$ at 09:30 Beijing Time (01:30 UTC) on 31 July and recovered at 20:40 Beijing Time (12:40 UTC) on 26 October. Mooring 2 was deployed at $114^{\circ} 54.324^{\prime} \mathrm{E}$ and $19^{\circ} 28.976^{\prime} \mathrm{N}$ at $12: 15$ Beijing Time (04:15 UTC) on 31 July and recovered at 08:30 Beijing Time (01:30 UTC) on 25 October. Note that observation in Station 2 (Tables 2 and 3) includes meteorology data from $4 \mathrm{~m}$ above the sea surface, as well as ocean temperature, salinity, and current from ocean surface to bottom. The meteorology data includes wind, air pressure, humidity, and temperature.

\subsection{Typhoons Sarika and Haima}

The best-track datasets of tropical cyclones were obtained from the Joint Typhoon Warning Center (JTWC), the Japan Meteorological Agency (JMA), and the China Meteorological Administration (CMA) [53] (Table 1). The TC tracks from the three sources were observed to be quite consistent (Figure 1). Sarika was formed in the northwest of the Pacific Ocean $\left(129.7^{\circ} \mathrm{E}, 12.5^{\circ} \mathrm{N}\right)$ at 18:00 UTC on October 12, moved northwestward, and grew from a tropical depression into a typhoon. It travelled through the Philippines, with its maximum wind speed reaching $42 \mathrm{~m} / \mathrm{s}$, and then weakened after entering the South China Sea, where its maximum wind speed fell to $38 \mathrm{~m} / \mathrm{s}$. When it travelled through our observation array, its translational speed was $\sim 6.53 \mathrm{~m} / \mathrm{s}$. Stations 1 and 2 were respectively biased by $\sim 15.77$ and $\sim 254.49 \mathrm{~km}$ to the right side of Sarika's track. Beyond the observation array, Sarika quickly weakened and dissipated after making landfall on the Hainan Island and the adorning mainland. 




Figure 1. Tracks of Typhoons Sarika and Haima obtained from the Joint Typhoon Warning Center (JTWC) data (orange), Japan Meteorological Agency (JMA) data (brown), and China Meteorological Administration (CMA) data (black), showing their positions every $6 \mathrm{~h}$ (dots). The text boxes point to the UTC 00:00 of the positions everyday, show the dates, sustained maximum wind speed, and central pressure obtained from the CMA data. The red numbers indicate the positions of the observation stations. The background shade indicates the topography.

Haima was also formed in the northwest of the Pacific Ocean $\left(144.4^{\circ} \mathrm{E}, 7.2^{\circ} \mathrm{N}\right)$ at 12:00 UTC on October 14. It moved northwestward, growing from a tropical depression into a super typhoon, and travelled through the Philippines with its maximum wind speed reaching $68 \mathrm{~m} / \mathrm{s}$. It weakened after entering the South China Sea, where the maximum wind speed fell to $42 \mathrm{~m} / \mathrm{s}$, and travelled through our observation array with a translation speed of $\sim 7.18 \mathrm{~m} / \mathrm{s}$. Stations 1 and 2 were respectively biased by $\sim 535.57$ and $\sim 208.44 \mathrm{~km}$ to the right side of Haima's track (Table 4 ). Beyond the observations array, Haima quickly weakened and dissipated after making landfall on the mainland. 
Table 4. Details of Typhoons Sarika and Haima when closest to Stations 1 and 2 *.

\begin{tabular}{ccccc}
\hline & Sarika-S1 & Sarika-S2 & Haima-S1 & Haima-S2 \\
\hline Longitude $\left({ }^{\circ} \mathrm{E}\right)$ & 112.168 & 114.907 & 112.168 & 114.907 \\
Latitude $\left({ }^{\circ} \mathrm{N}\right)$ & 18.036 & 19.469 & 18.036 & 19.469 \\
Ocean Depth $(\mathrm{m})$ & $\sim 2400$ & $\sim 1450$ & $\sim 2400$ & $\sim 1450$ \\
Distance to tropical cyclone track $(\mathrm{km})$ & 15.77 & 254.49 & -535.57 & -208.44 \\
Closest time & $10 / 17,13: 00$ & $10 / 17,00: 00$ & $10 / 20,18: 00$ & $10 / 20,18: 00$ \\
\hline
\end{tabular}

* Depth refers the ocean depth at the observation station. Positive (negative) values of the distance to tropical cyclone track refers to the right (left) side of the track.

As shown in Table 5, the nondimensional translation speed $(S)$ is the ratio of the local inertial period to the translation speed of the TC [44,54]. The values of $S$ for Sarika and Haima were close to 1 , indicating that the oceanic responses to the two TCs were significantly biased to the right. The Rossby number of the mixed layer current $(Q)$ is the ratio of the horizontal advection of the momentum to the Coriolis force [54]. The $Q$ values for Sarika and Haima indicated insignificant nonlocal effects of the horizontal advections during the forced stages of the typhoons.

Table 5. Parameters of Typhoons Sarika and Haima *.

\begin{tabular}{ccc}
\hline & Sarika & Haima \\
\hline Maximum wind speed $\left(V_{\max }, \mathrm{m} / \mathrm{s}\right)$ & 38.00 & 42.00 \\
Translational speed $(U, \mathrm{~m} / \mathrm{s})$ & 6.53 & 7.18 \\
Radius of fastest wind $\left(r_{m}, \mathrm{~km}\right)$ & $120.0(37.04)$ & $150.0(46.3)$ \\
Mixed layer depth $\left(h_{\operatorname{mix}}, \mathrm{m}\right)$ & 45 & 50 \\
Nondimensional translational speed, $\left(S=\frac{U}{r_{m} f}\right)$ & $1.161(3.760)$ & $1.021(3.308)$ \\
Rossby number of mixed layer current, $\left(\mathrm{Q}=\frac{\tau_{\max }}{\rho \mathrm{h}_{\operatorname{mix}} \mathrm{Uf}}\right)$ & 0.253 & 0.257 \\
\hline
\end{tabular}

* The values were calculated using the China Meteorological Administration (CMA) best-track data when the two typhoons were close to our observation array. Values in brackets were obtained from the Joint Typhoon Warning Center (JTWC) data set. $r_{m}$ without bracket is calculated from observations using the method of [15], which is used for the wind field of the model simulation. $h_{\text {mix }}$ is estimated using the depth that was $0.5^{\circ} \mathrm{C}$ cooler than ocean surface with the temperature profile at $\mathrm{S} 2$ that was one inertial period on average after the two tropical cyclones. $f$ was calculated using the average latitude of $\mathrm{S} 1, \mathrm{~S} 2$, and $\mathrm{S} 3\left(18.753^{\circ} \mathrm{N}\right)$.

\subsection{Typhoons Sarika and Haima}

The numerical model used in this study was a three-dimensional version of the Price-Weller-Pinkel model (3DPWP) [54,55], which has been used successfully in previous studies to simulate and understand the physical processes involved in the oceanic response to a TC [15-17,22,56-58]. The model domain used here spans $1200 \mathrm{~km}$ in the across-track direction and $5600 \mathrm{~km}$ in the along-track direction, with a horizontal resolution of $8 \mathrm{~km}$ and a vertical resolution of $10 \mathrm{~m}$ with the ocean depth of $1450 \mathrm{~m}$. The time resolution is $120 \mathrm{~s}$. The model starts from rest, and the initial temperature and salinity were set to be horizontally homogeneous using the average profiles from Station 2 during UTC 00:00 on 14 October to UTC 00:00 on 16 October for Sarika and during UTC 00:00 on 18 October to UTC 00:00 on 20 October for Haima (see Figure 2). The Coriolis parameter for the model was $4.861 \times 10^{-3} \mathrm{~s}^{-1}$, which corresponds to the latitude of Station $2\left(19.469^{\circ} \mathrm{N}\right)$ and an inertial period of $35.91 \mathrm{hr}$. The parameters of wind field for Sarika and Haima in model were the same as the values in Table 3, see [15] for more details of the model setup. 
(a) Temperature $\left({ }^{\circ} \mathrm{C}\right)$

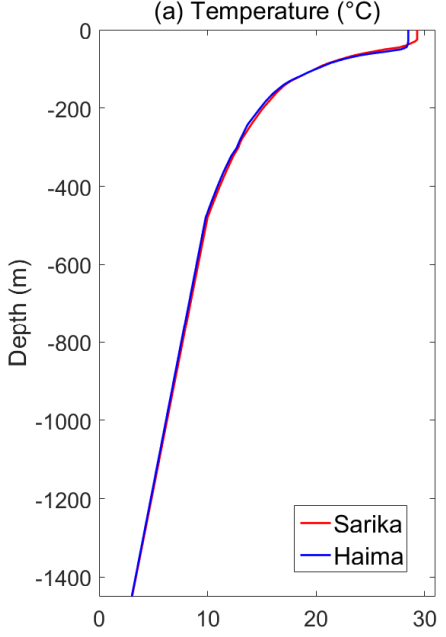

(b) Salinity (PSU)

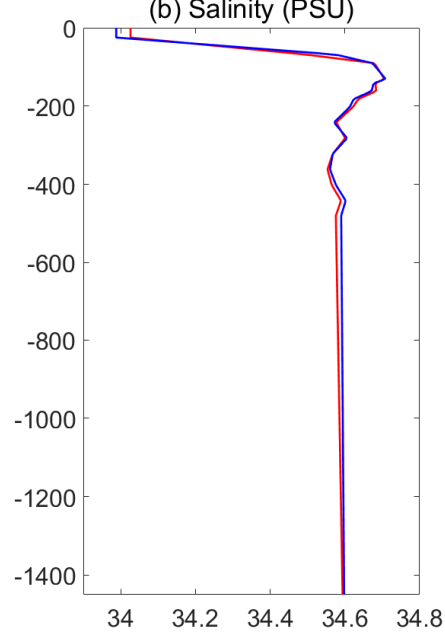

(c) Density $\left(\mathrm{kg} / \mathrm{m}^{3}\right)$

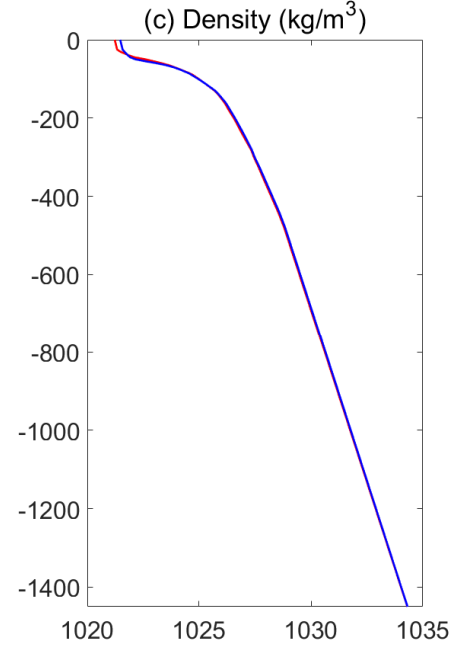

Figure 2. Initial temperature, salinity, and density profiles for Sarika (red) and Haima (blue) in 3DPWP model simulation. Profiles for Sarika (Haima) are averaged over UTC 00:00 on 14 (16) October to UTC 00:00 on 16 (20) October of the observation at Station 2. 3DPWP: three-dimensional version of the Price-Weller-Pinkel model.

\section{Results}

\subsection{Results of Remote Sensing Using Multiple Satellite}

\subsubsection{Cloud and Rainfall}

The cloud-top brightness temperatures shown in Figure $3 a-h$ reveal that the structures of Sarika and Haima were relatively circular before they passed through the Philippines. Note that lower cloud-top brightness temperature represents higher cloud-top height and more convection. The clouds from the two typhoons on the right side of the tracks weakened after entering the South China Sea, resulting in a leftward asymmetry of the brightness temperatures (Figure $3 b, f)$; this may be due to the local land-sea distribution. The clouds gradually dissipated after making landfall on the Chinese mainland. Station 1 was in the path of the eye of Sarika (Figure 3c), while Station 2 was on right part of the spiral cloud band of Sarika. Four days later, the left part of the spiral cloud band of Haima influenced both Stations 1 and 2. The rainfall (Figure 3i-p) mainly occurred near the eyewall, while the spiral cloud band showed some weak precipitation. Both Stations 1 and 2 experienced rainfall from both Sarika and Haima. 

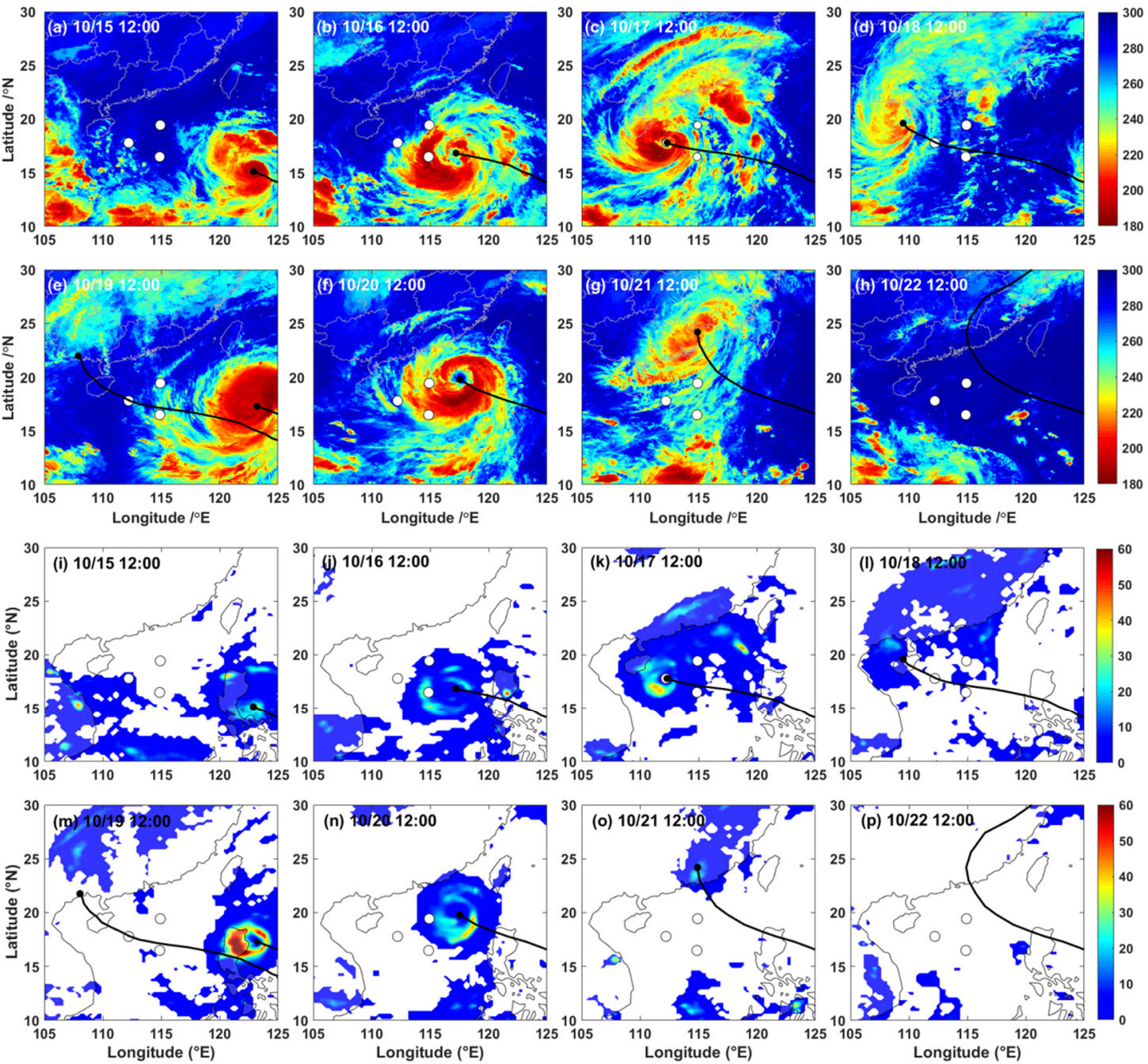

Figure 3. (a-h) Cloud-top brightness temperatures obtained by the Himawari-8 satellite at 12:00 UTC between October 15 and 22, and (i-p) corresponding rainfall data obtained by the CPC MORPHing technique (CMORPH) data. The white hollowed dots indicate the buoy and mooring stations; the black lines indicate the tropical cyclone tracks; and the black dots indicate the centers of the tropical cyclones.

\subsubsection{Wind and Sea Surface Heights}

A background northeast wind prevailed before the two typhoons (Figure 4a). During Sarika and Haima, the wind distribution was in accordance with the cloud and precipitation (Figure $4 \mathrm{a}-\mathrm{h}$ ). However, contrary to the cloud and precipitation, the wind was stronger on the right side of the tracks of Sarika and Haima when they travelled through our observation array (Figure $4 \mathrm{~b}, \mathrm{f}$ ). The sea surface heights exhibited negative and positive anomalies at Stations 1 and 2 (see Figure 4i-p). The geophysical current anomaly indicated that Station 2 was on the boundary of a cyclonic (cold) eddy, which moved only a little during the two typhoons. 



Figure 4. (a-h) Wind data obtained by CCMP at 12:00 UTC between October 15 and 22 and (i-p) CMEMS sea surface height (color) and geostrophic current (vector) anomalies. CCMP: cross-calibrated multi-platform. CMEMS: Copernicus Marine and Environment Monitoring Service.

\subsubsection{Sea Surface Temperature and Salinity}

Both Sarika and Haima caused sea surface cooling (Figures $5 a-h$ and $6 a-h$ ), with the cooling strongest one day after the two typhoons. The cooling was biased a little to the right side of the typhoon tracks and gradually recovered after the cold wake. Station 1 was just at the core of the cold wake of Sarika, while Station 2 was on the boundary of the cold wake. Conversely, Station 1 was away from the cold wake of Haima, while Station 2 was once again on the boundary of the typhoon's cold wake. Similar to the sea surface temperature anomalies, the sea surface salinity was also increased by Sarika and Haima, with the anomalies in this case seeming to be biased to the left and right side of the tracks of the two typhoons, respectively (see Figures $5 i-p$ and $6 i-p$ ). The heavy rainfall of Haima might have refreshed the left side of its track a little. It should be noted that the maximum surface temperature cooling $\left(\sim 4^{\circ} \mathrm{C}\right)$ and salinity increase $(\sim 1.2 \mathrm{psu})$ caused by Sarika were greater than those caused by Haima $\left(\sim 2{ }^{\circ} \mathrm{C}\right.$ and $\sim 0.6 \mathrm{psu}$, respectively), possibly because the water was already mixed by Sarika, and hence the cooling cannot be as much during Haima. However, it may also due to the different local initial stratifications. 

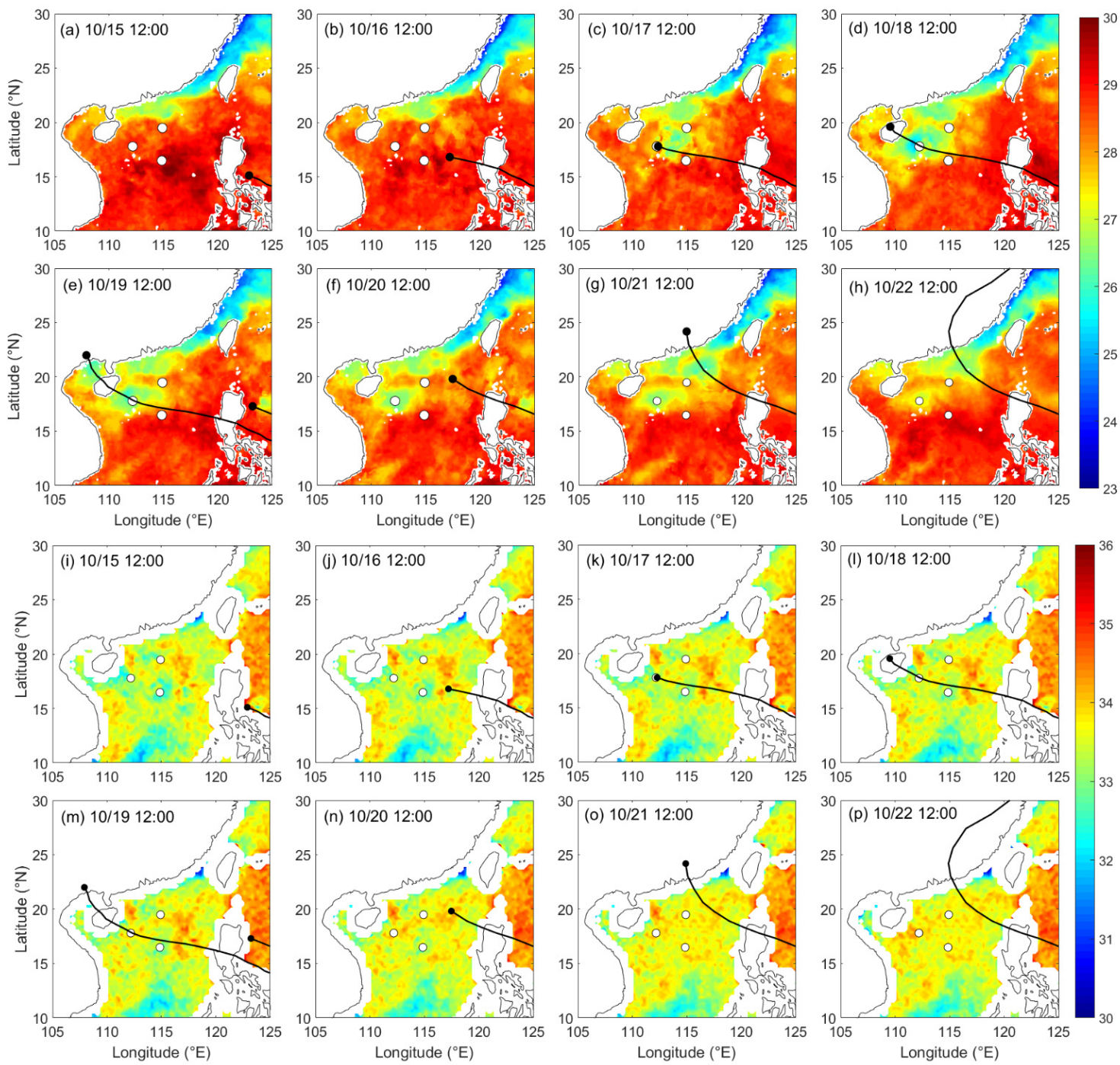

Figure 5. (a-h) Microwave optimally interpolated (OI) sea surface temperature, and (i-p) soil moisture active passive (SMAP) sea surface salinity at 12:00 UTC between October 15 and 22. 

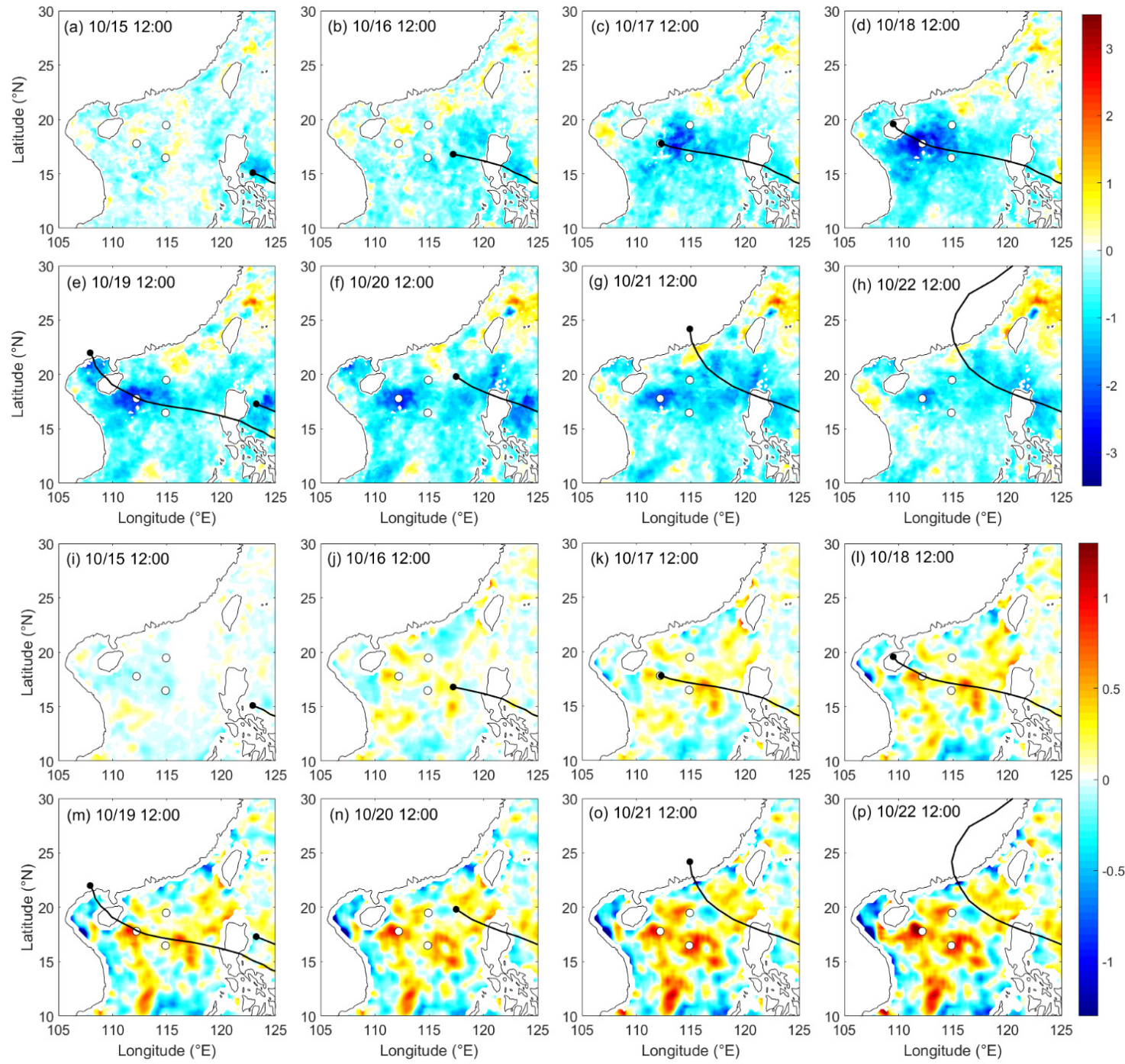

Figure 6. (a-h) Sea surface temperature and (i-p) sea surface salinity anomalies at 12:00 UTC between October 15 and 22. The anomalies are relative to the conditions at 12:00 UTC on October 14 .

\subsection{Buoy and Mooring Observation Results at Station 2}

\subsubsection{Air-Sea Interface}

Figure 7 shows a background wind from the north-east with a velocity of $\sim 10 \mathrm{~m} / \mathrm{s}$ at Station 2 before Sarika, which is consistent with the satellite observations in Figure 3. The background air pressure and humidity were $\sim 1010 \mathrm{hPa}$ and $\sim 83 \%$, respectively. The wind, air pressure, and air humidity approached $\sim 20 \mathrm{~m} / \mathrm{s}, \sim 1000 \mathrm{hPa}$, and $\sim 90 \%$ when Sarika was close to Station 2 and $\sim 20 \mathrm{~m} / \mathrm{s}$, $\sim 996 \mathrm{hPa}$, and $\sim 90 \%$ when Haima was close (Figure 7a,c,e). The wind rotated clockwise under Sarika and anticlockwise under Haima, in accordance with the fact that Station 2 was on the right and left sides of the tracks of Sarika and Haima, respectively (Figure 7b). Note that wind speed observed by Station 2 was consistent with the data from satellite (Figure 7a), but wind direction was more irregular than satellite data (Figure $7 b$ ). 
(a) Wind Speed $(\mathrm{m} / \mathrm{s})$, Station 2

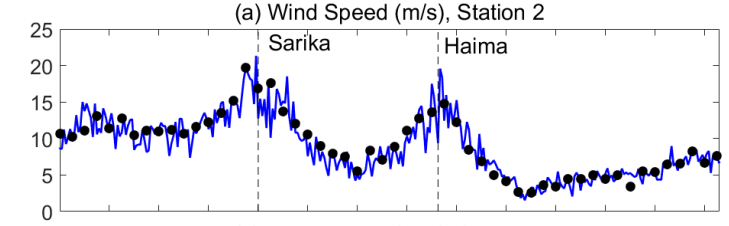

(c) Air Pressure (hpa), Station 2
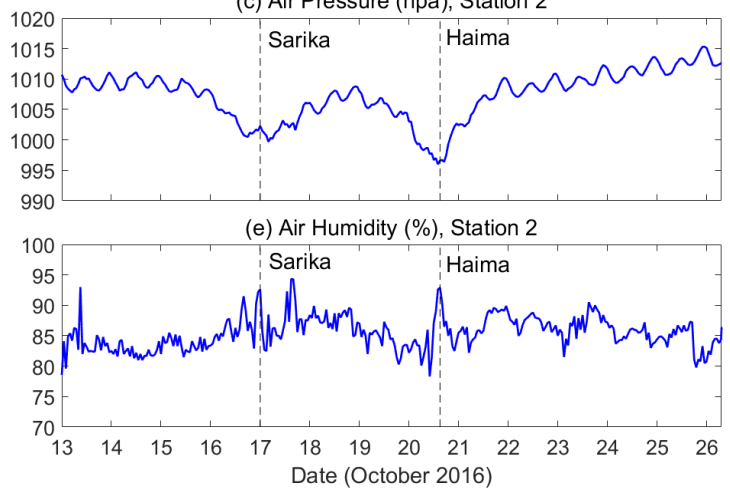

(b) Wind Direction $\left(^{\circ}\right)$, Station 2

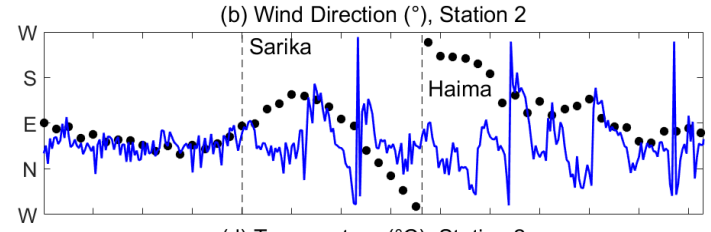

(d) Temperature $\left({ }^{\circ} \mathrm{C}\right)$, Station 2
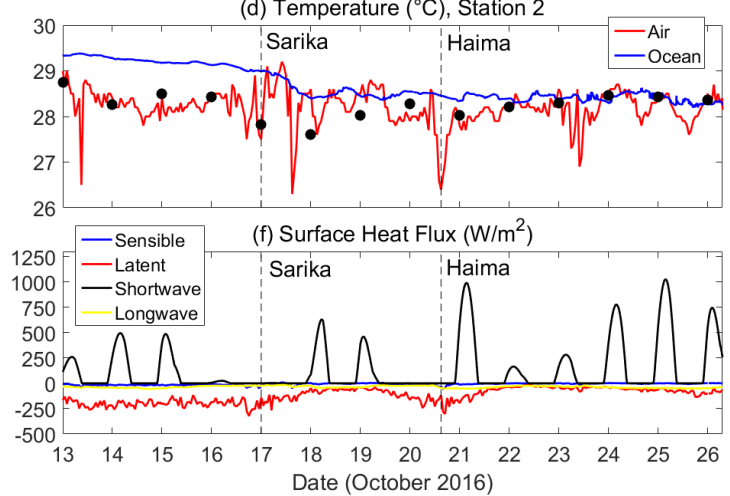

Figure 7. Time series of the (a) sustained surface wind speed, (b) wind direction, (c) air pressure, (d, red) surface air temperature, (d, blue) sea surface temperature, (e) air humidity, surface fluxes of the (f, blue) sensible heat, (f, red) latent heat, (f, black) short wave radiation, and (f, orange) long wave radiation at Station 2 during Sarika and Haima. Regarding the wind directions, N, W, S, and E indicate the approach directions of the winds, namely, north, west, south, and east, respectively. The vertical black dashed lines represent the times when Sarika and Haima were closest to Station 2. Black dots in $(\mathbf{a}, \mathbf{b}, \mathbf{d})$ were the remote sensingsatelliate data of cross-calibrated multi-platform (CCMP) wind and Microwave optimally interpolated sea surface temperature (OI SST).

The initial surface air and sea surface temperatures were $\sim 28.5$ and $\sim 29.5{ }^{\circ} \mathrm{C}$ at stations 1 and 2 , respectively (Figure $7 \mathrm{~d}$ ); Sarika reduced the former by $\sim{ }^{\circ} \mathrm{C}$ to the minimum value of $28.4^{\circ} \mathrm{C}$ around UTC 00:00 on 18 October, one day after the typhoon. Haima also cooled the sea surface temperature slightly. The sea surface temperature in Figure $7 \mathrm{~d}$ is the temperature observed by the sensor at the shallowest depth of $22 \mathrm{~m}$. It is interesting that the surface air temperature increased slightly, to $\sim 29^{\circ} \mathrm{C}$, during the forced stage of Sarika and then fell to a minimum value of $\sim 26.3{ }^{\circ} \mathrm{C}$ after one day. The sea surface temperature was slightly higher than the surface air temperature, although the opposite was sometimes true (Figure 7d), resulting in a reversal of the ocean surface sensible heat flux. Note that the sea surface temperature from satellite data (OI SST) was lower than the sea surface temperature observed by Station 2 but more consistent with surface air temperature (Figure 7d), indicating that OI SST may reflect the air temperature rather than the ocean temperature in the air-sea surface. Another air temperature minimum of $\sim 26.5^{\circ} \mathrm{C}$ occurred when Haima was closest to Station 2 . The surface heat flux (Figure 7f) revealed that the shortwave radiation and latent heat flux controlled the air-sea interface heat flux during Sarika and Haima (Figure 7f). The ocean gained heat from the shortwave radiation and lost heat to the air through the latent heat flux.

\subsubsection{Ocean Current}

Before the two typhoons, the background upper and bottom ocean currents were north-eastward and south-westward respectively at Station 2 (Figure $8 \mathrm{a}-\mathrm{d}$ ). Then near-inertial oscillations occurred after Sarika and Haima, with the maximum current speed reaching $\sim 80 \mathrm{~cm} / \mathrm{s}$ in the mixed layer. The phase of the near-inertial current in the vertical direction tilted with time during the relaxation stage of the two typhoons. That is, the current phase deeper in the ocean delayed the one at a shallower level, with the delay increasing with time. This was due to the dispersion of the near-inertial waves, the process of which has been previously explained $[25,26,59]$. The results of the spectral analysis in Figure $8 \mathrm{e}-\mathrm{h}$ reveals significant near-inertial, diurnal, and semidiurnal frequency signals of the current 
from the ocean surface to the bottom. There was no significant blue shift occurred at Station 2, which is consistent with the fact that Station 2 was so far from both Sarika $(254.49 \mathrm{~km})$ and Haima $(-208.44 \mathrm{~km})$ that the near-inertial current might have been dispersed before it reached Station 2, leaving mainly the inertial frequency. It should be noted that there was also a weak super-inertial wave signal with twice the inertial frequency $(2 f)$. The super-inertial wave signal has been previously reported to be the cause of the nonlinear effect in the current response $[27,28]$.
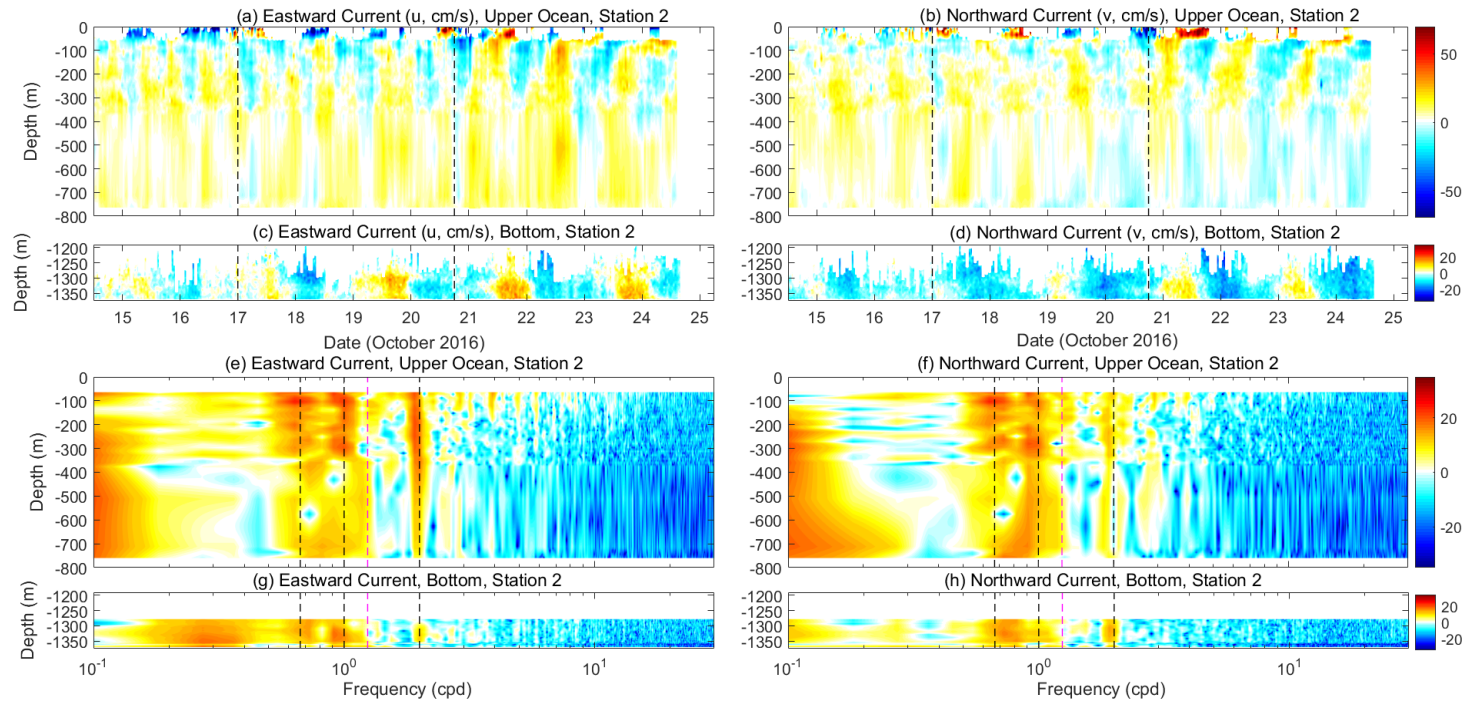

Figure 8. Eastward and northward current (a-d) at Station 2, and their spectra between October 13 and $24(\mathbf{e}-\mathbf{h})$. The vertical black dashed lines indicate the inertial, diurnal, and semidiurnal frequencies. The vertical violet dashed lines indicate twice the inertial frequency.

\subsubsection{Ocean Temperature}

Oceanic temperature can be advected by current, so we can find diurnal variation and weak semidiurnal variation during observation (Figures 9a and 10a), as well as the near-inertial variations occurred by the TCs.

At Station 2 (with the operation of Buoy 2 and Mooring 2, Figures 9 and 10), there was a "cold-warm-cold" vertical temperature anomaly structure in the upper ocean after the two typhoons. The depth of the mixed layer increased rapidly from $\sim 30 \mathrm{~m}$ to $\sim 50 \mathrm{~m}$ within $3 \mathrm{hr}$ on October 16, eventually reaching its maximum value of $\sim 54 \mathrm{~m}$ several hours before the time Sarika was closest to Station 2. Sarika cooled the upper ocean by $\sim 1{ }^{\circ} \mathrm{C}$ from the surface up to a depth of $\sim 40 \mathrm{~m}$. In addition, it warmed the ocean subsurface by $\sim 1{ }^{\circ} \mathrm{C}$ between depths of $\sim 40$ and $70 \mathrm{~m}$, with a weak warming anomaly further extending to a depth of $\sim 100 \mathrm{~m}$. Sea surface temperature started to decrease when mixed layer depth deepened, and sea surface temperature reached its minimum near the end of upwelling branch. After removing the inertial period signal, a net warming anomaly was apparently caused by downwelling when Sarika was closet to Buoy 2 in the upper ocean (Figure 9e). The upwelling branch was effective when Haima was close to Station 2 (October 20-21), and the mixed layer depth was thus shallow at $\sim 35-60 \mathrm{~m}$, with the $15{ }^{\circ} \mathrm{C}$ isotherm lifted from $\sim 250 \mathrm{~m}$ to $\sim 150 \mathrm{~m}$. Another downwelling seemed to occur $\sim 1$ day after when Haima was closest to Buoy 2, and it further caused an $\sim 2{ }^{\circ} \mathrm{C}$ warming anomaly in the ocean subsurface, with the main warming anomaly reaching a depth of $\sim 90 \mathrm{~m}$, and a weak warming anomaly further extending to a depth of $\sim 150 \mathrm{~m}$ (Figure 9a). The upper ocean heat content increased sequentially to $\sim 50 \mathrm{~m}^{\circ} \mathrm{C}$ and $\sim 100 \mathrm{~m}^{\circ} \mathrm{C}$ after Sarika and Haima. Mooring 2 (Figure 10) showed that the warming anomaly caused by the downwelling reached $\sim 500 \mathrm{~m}$, while Haima downward pushed it into $\sim 600 \mathrm{~m}$. 
(a) Temperature $\left(\mathrm{T},{ }^{\circ} \mathrm{C}\right)$, Buoy 2

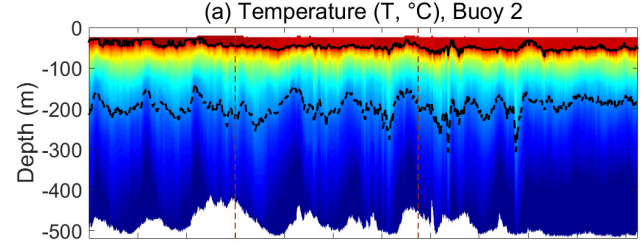

(d) Temperature Amonlay $\left(\Delta \mathrm{T},{ }^{\circ} \mathrm{C}\right)$, Buoy 2

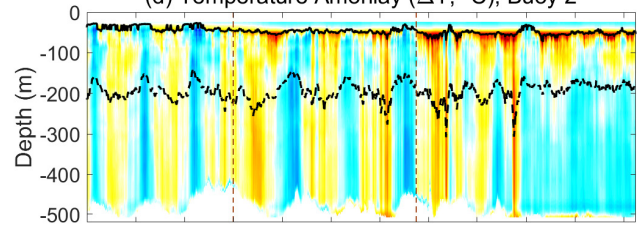

(b) Heat $\left(m^{\circ} \mathrm{C}\right)$, Buoy 2

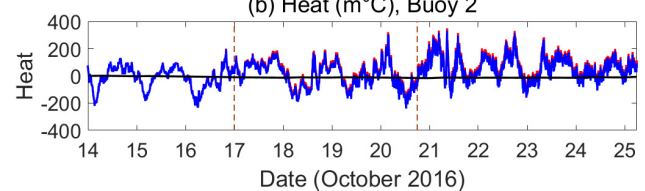

(b) Net Temperature $\left(\mathrm{Tn},{ }^{\circ} \mathrm{C}\right)$, Buoy 2

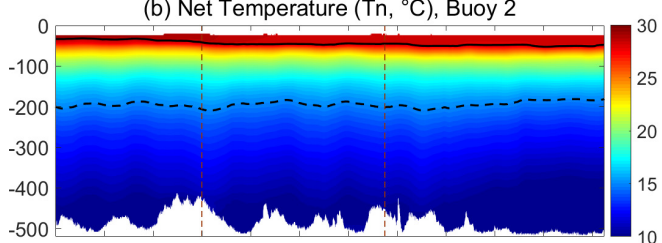

(e) Net Temperature $\left(\Delta \operatorname{Tn},{ }^{\circ} \mathrm{C}\right)$, Buoy 2

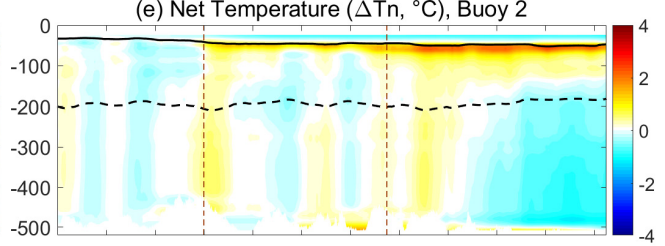

(d) Net Heat $\left(m^{\circ} \mathrm{C}\right)$, Buoy 2

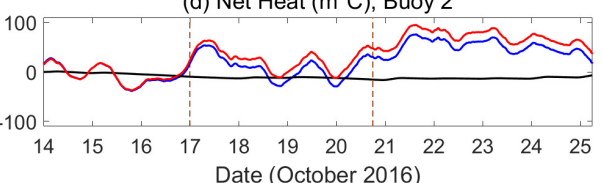

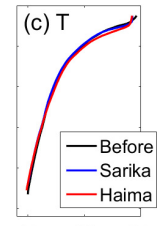

$10 \quad 20 \quad 30$

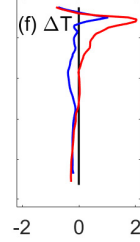

$\left({ }^{\circ} \mathrm{C}\right)$

Figure 9. Temperature (a), temperature anomaly $(\mathbf{d})$ and their net values $(\mathbf{b}, \mathbf{e})$ during Sarika and Haima at Buoy 2. Average temperature (c) and temperature anomaly (f) profiles before the two typhoons (black; averaged between 14 and 16 October), after Sarika (blue; averaged over one inertial period after 18 October), and after Haima (red; averaged over one inertial period after 22 October). The black solid lines in $(\mathbf{a}, \mathbf{b}, \mathbf{d}, \mathbf{e})$ indicate the mixed layer depth, which is the depth at which the temperature is $0.5^{\circ} \mathrm{C}$ lower than the surface layer temperature. The black dashed lines indicate the $15^{\circ} \mathrm{C}$ isotherm. $(\mathbf{g}, \mathbf{h})$ Accumulated surface heat flux (black lines), heat anomaly from 0 to $160 \mathrm{~m}$ (red lines), and their sum (blue lines) at Buoy 2. The vertical brown dashed lines represent the times when Sarika and Haima were closest to Station 2 . The temperature observed by the sensor near the surface (at a depth of $22 \mathrm{~m}$ ) was used for the heat content calculations for shallower depths.

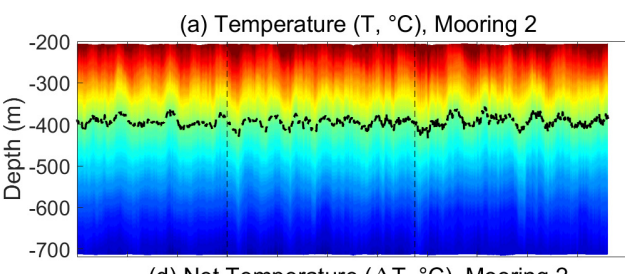

(d) Net Temperature $\left(\Delta \mathrm{T},{ }^{\circ} \mathrm{C}\right)$, Mooring 2

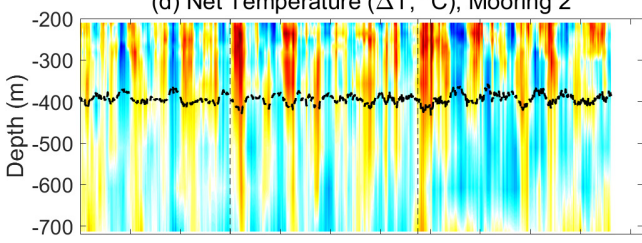

(g) Heat $\left(m^{\circ} \mathrm{C}\right)$, Mooring 2

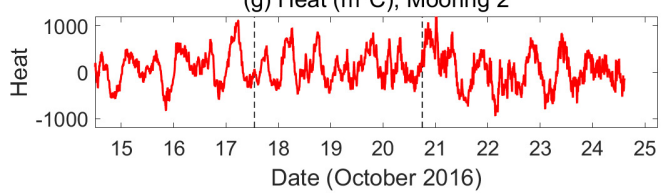

(b) Net Temperature $\left(\mathrm{Tn},{ }^{\circ} \mathrm{C}\right)$, Mooring 2

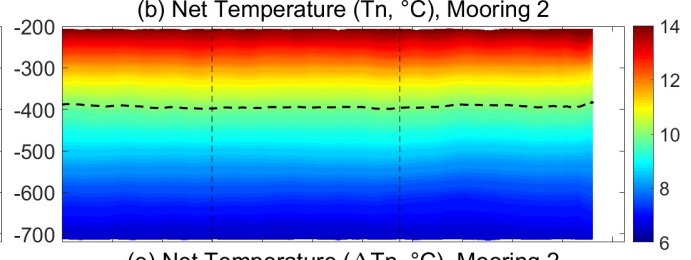

(e) Net Temperature $\left(\Delta \mathrm{Tn},{ }^{\circ} \mathrm{C}\right)$, Mooring 2

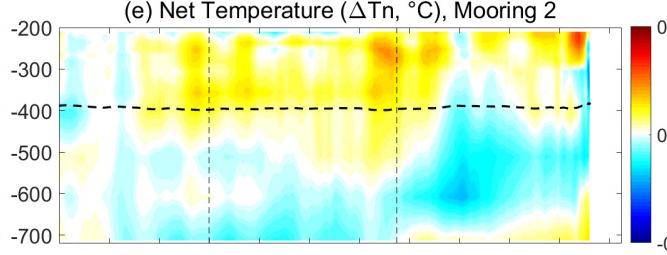

(h) Heat $\left(m^{\circ} \mathrm{C}\right)$, Mooring 2

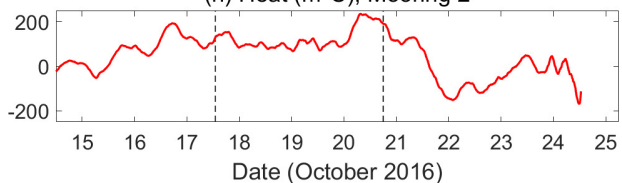



$\begin{array}{lllll}6 & 8 & 10 & 12 & 14\end{array}$

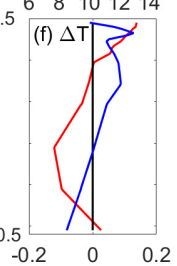

$\left({ }^{\circ} \mathrm{C}\right)$

Figure 10. Mooring 2 parameters corresponding to those in Figure 9. The heat content anomaly and net heat content anomaly in $(\mathbf{g}-\mathbf{h})$ are between $210 \mathrm{~m}$ to $500 \mathrm{~m}$ in the observation (red lines).

\subsubsection{Ocean Salinity}

Figure 11 shows the salinity response during Sarika and Haima at Station 2. As the salinity sensors may have some deviations and inaccuracy, the analysis of salinity response should be careful. Because the subsurface salinity reached a maximum in Station 2, upwelling (downwelling) caused salinity increase (decrease) upper (lower) than the subsurface maximum. A weak updrift of salinity profile during 16 October at Buoy 2 (Figure 11a-c) caused a weak increase of $\sim 0.07$ psu in the salinity 
between $40 \mathrm{~m}$ and $80 \mathrm{~m}$ after Sarika. However, Sarika's rainfall reversed the surface salinity anomaly to $\sim-0.03 \mathrm{psu}$. Haima's rainfall further refreshed the mixed layer, reducing the surface salinity anomaly to $-0.1 \mathrm{psu}$; it also changed the positive salinity anomaly between depths of 40 and $80 \mathrm{~m}$ into a negative anomaly.
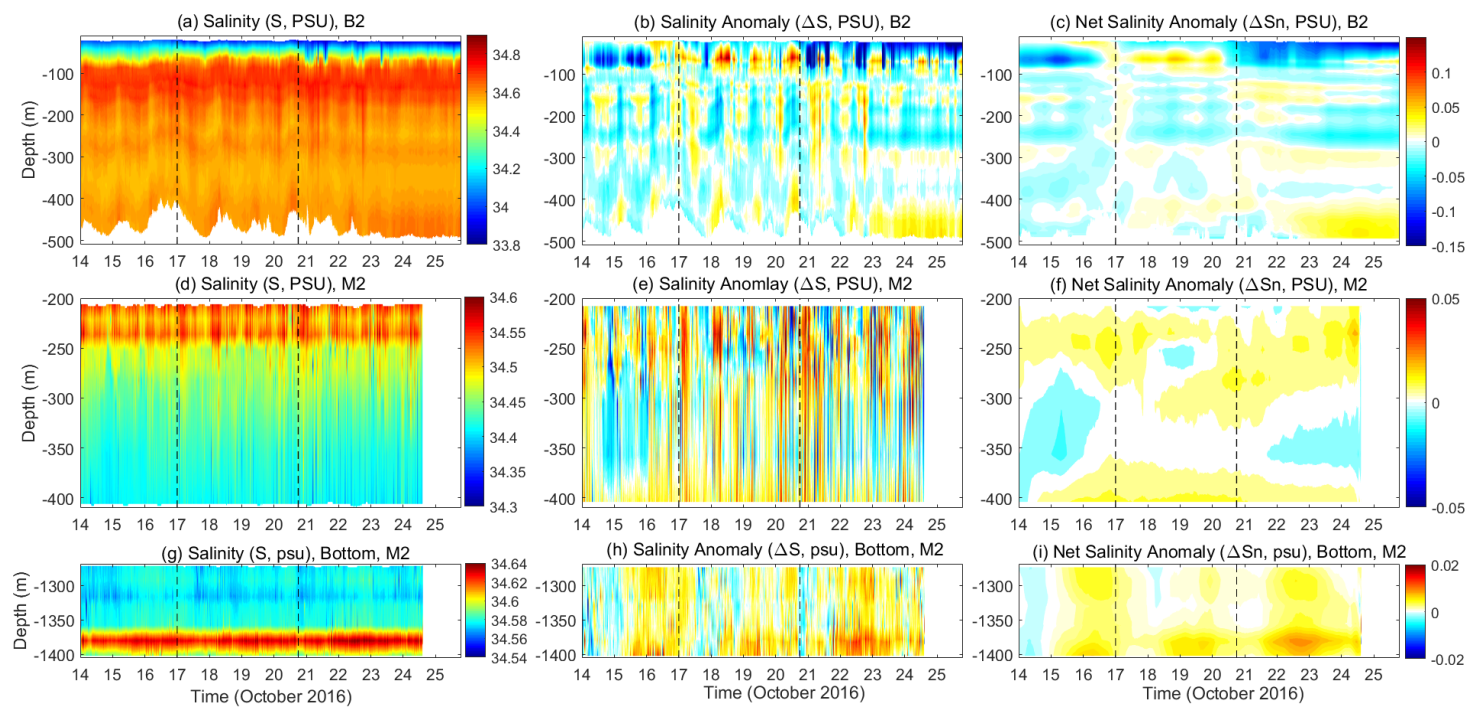

Figure 11. Salinity, salinity anomaly, and net salinity anomaly during Sarika and Haima at Buoy 2 $(\mathbf{a}-\mathbf{c})$ and Mooring $2(\mathbf{d}-\mathbf{i})$. Net salinity anomaly is the one inertial period running mean of the salinity anomaly. The salinity anomaly was calculated as the salinity minus the average salinity over the period UTC 00:00 on 14 October to UTC 00:00 on 16 October. Dashed lines represent the time that Sarika and Haima were closest to the stations.

\subsubsection{Mechanisms of Upper Temperature Response at Station 2}

In order to further analyze the mechanisms of upper ocean temperature response to the two TCs, we used a three dimensional model (3DPWP) to reproduce the ocean response during Sarika and Haima separately (Figure 12). Consistent with the observation in Figure 8, Sarika and Haima both caused sea surface cooling and subsurface warming anomaly at Station 2 (Figure 12c,d,k,l). The surface cooling was mainly caused by mixing and partly by the horizontal advection during the forced stage (Figure 12e,f,m,n). Note that the maximum sea surface cooling was nearly one day after Sarika (Figures $7 \mathrm{c}$ and 12c), when the combination cooling effects of mixing and horizontal advection were strongest, nearly the half period of the first near-inertial oscillation. The sea surface cooling during Haima (Figures 7c and 12k) seems influenced by the oscillation of surface cooling caused by Sarika (Figure 12c) because the surface cooling caused by Haima (Figure 12k) was weak. The vertical advection induced periodic warming (Figures $11 \mathrm{o}$ and $12 \mathrm{~g}$ ) and net warming (Figure 12h,p) in subsurface and deeper ocean. The subsurface warming during Sarika was caused by the combination effect of mixing and downwelling, while the subsurface warming during Haima was mainly caused by downwelling. 

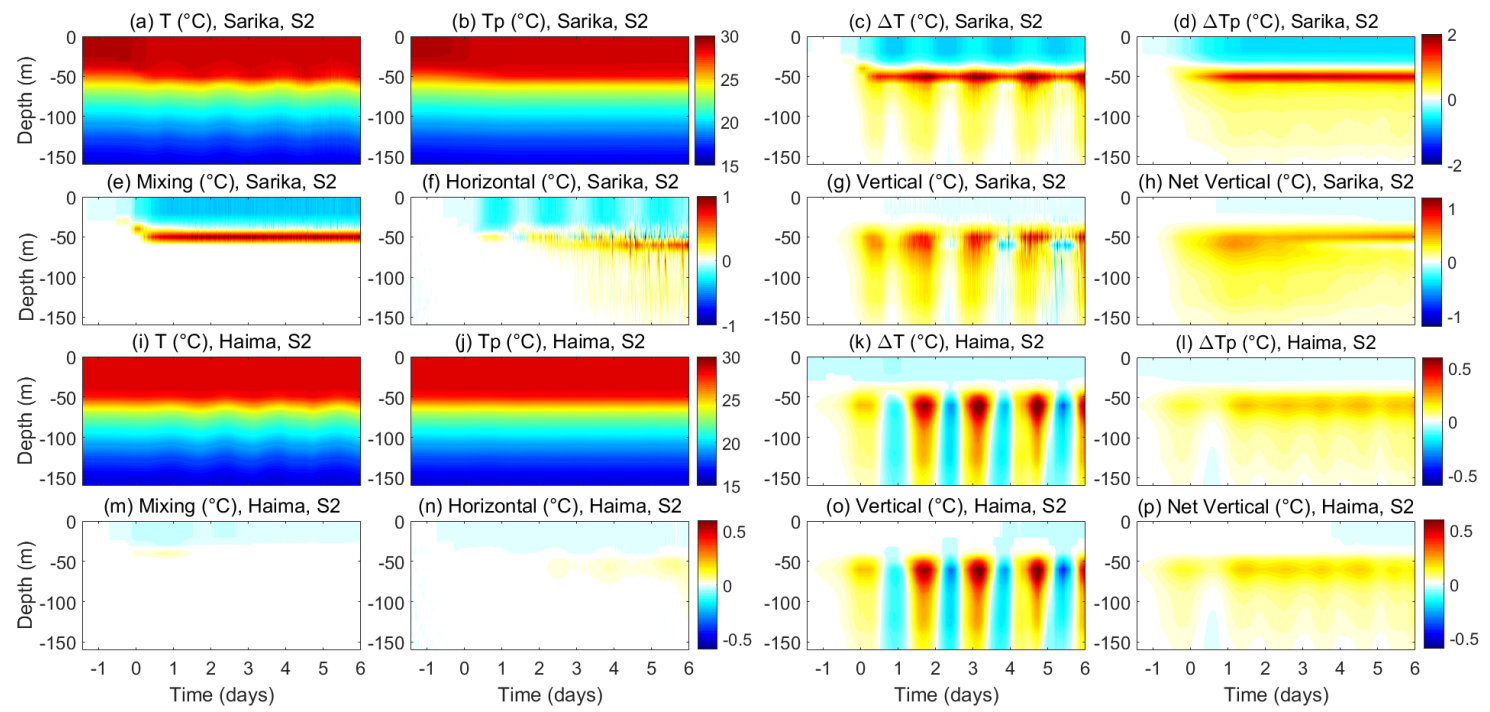

Figure 12. Change of temperature $(\mathrm{T})$, net temperature $(\mathrm{Tp})$, temperature anomaly $(\Delta \mathrm{T})$, net temperature anomaly $(\Delta \mathrm{Tp})$, and temperature change caused by mixing, horizontal advection, vertical advection and net vertical advection simulated by 3DPWP model during Sarika (a-h) and Haima (i-p).

In a word, Sarika and Haima both induce net surface cooling and net subsurface/deeper ocean warming. Surface cooling was due to the effects of mixing and horizontal advection, while subsurface warming was induced by the combination effects of mixing and downwelling (Sarika) or mainly downwelling (Haima). Downwelling also further warmed the deeper ocean.

\section{Discussion}

Here, we simplify the response of the upper ocean temperature at Station 2 to a TC. Because the surface heat flux made only a little contribution to the change in the upper ocean heat content (Figure $9 b, d$ ), the temperature response at Station 2 was therefore mainly controlled by mixing and advection (vertical and horizontal).

Figure 13 is a simplified sketch of the temperature response at Station 2. In the case of only mixing (Figure 13a), the surface warming anomaly and subsurface cooling anomaly are comparable, with the change in the upper ocean heat content being zero. Because Sarika also caused downwelling, the temperature profile is pushed downward. In addition, when the mixed layer depth was increased through downwelling, the entrainment rate at the bottom of the mixed layer might have been weaker than the case of only mixing, resulting in weaker sea surface cooling. Horizontal advection also caused some cooling in the mixed layer. The subsurface warming anomaly caused by Sarika was greater than the surface cooling anomaly, resulting in a positive upper ocean heat (Figures $9 \mathrm{~d}$ and $13 \mathrm{~b}$ ). Haima further deepened the mixed layer, cooled surface, and warmed subsurface/deeper ocean through the same (but weaker) processes, with the combination of mixing and advection (Figure 12c) further increasing upper ocean heat content at Station 2 (Figures 9d and 13c). 


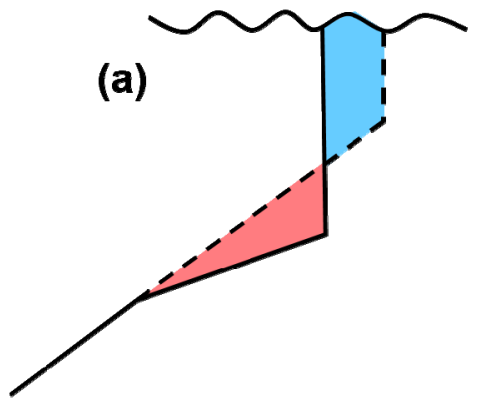

Mixing

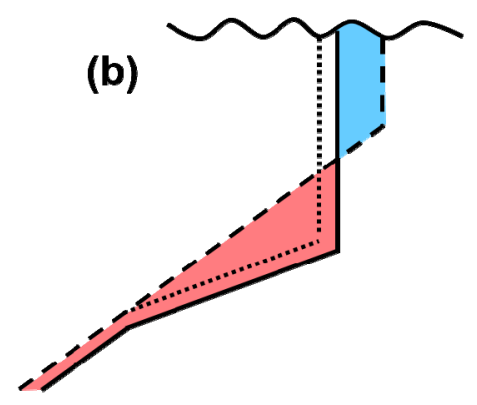

After Sarika

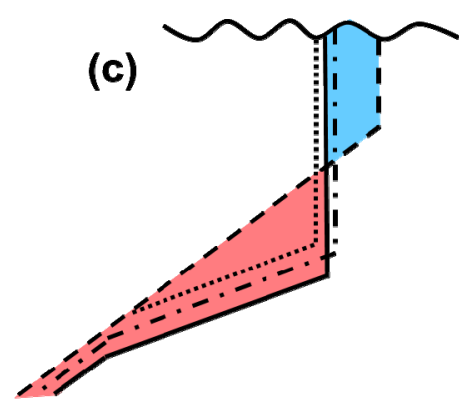

After Haima

Figure 13. Sketch of the vertical temperature profiles at Station 2 before (dashed lines) and after (solid lines) (a) only mixing, (b) Sarika, and (c) Haima. The dotted lines in (b) and (c) indicate the temperature profiles caused by only mixing, while the dot-dashed line in (c) indicates that caused by Sarika. The red shading indicates the warming anomaly, and the blue shading the cooling anomaly.

The upper ocean temperature response to the two sequential TCs at Station 2 was a special case because the temperature profile variation was caused by sequential mixing and downwelling. As observed in previous studies [15,22,30], the oceanic response to a TC at an observation station depends on the position of the station relative to the TC track, as well as the TC characteristics such as intensity, size, translation speed, and ocean stratification. For example, there is net upwelling near the TC track and net downwelling around the net upwelling zone [22], and the mixed layer depth varies with the TC translation speed [30]. So the temperature response to sequential TCs at a station can be complicated and different from Figure 13. In some regions with high ocean precipitation, the uniform-density mixed layer is shallower than the isothermal layer, and this generates a barrier layer that reduces the TC-induced vertical mixing and sea surface cooling $[60,61]$.

\section{Conclusions}

During their passage through the buoy and mooring array at our observation stations, the maximum wind speeds for Sarika and Haima were 38 and $42 \mathrm{~m} / \mathrm{s}$, respectively, with the winds biased to the right side of the TC tracks and the cloud and rainfall to the left. Sarika and Haima cooled the sea surface as much as $\sim 4$ and $\sim 2{ }^{\circ} \mathrm{C}$, respectively, and increased salinity as much as $\sim 1.2$ and $\sim 0.6 \mathrm{psu}$, respectively. The maximum sea surface cooling occurred one day after the passage of the respective TCs, with the heavy rainfall of Haima possibly refreshing the left side of its track.

Both Sarika and Haima increased the near-inertial oscillation from the upper ocean to the bottom at Station 2. The maximum current speed in the mixed layer was $\sim 80 \mathrm{~cm} / \mathrm{s}$. The phase delay of the increase in the near-inertial current in the deeper ocean was greater than that in the shallower ocean, resulting in an increase in the inclination of the current phase in the relaxation stage of the two typhoons. The near-inertial currents at Stations 2 caused no significant blue shifts in the inertial frequency, indicating that the current at Station 2 propagated away from the source region. The current spectrum shows weak signal at twice the inertial frequency ( $2 f)$.

At Station 2, the two typhoons caused "cold-warm-cold" vertical temperature anomalies. The surface heat flux did not significantly impact the heat content variation of the upper ocean during either of the two typhoons, so the upper ocean thermal response was mainly due to the internal ocean processes (mixing and advection). Sarika deepened the mixed layer, cooled the sea surface by $\sim-1{ }^{\circ} \mathrm{C}$, and warmed the subsurface by $\sim{ }^{\circ} \mathrm{C}$; it also caused a net downwelling that increased the heat content of the upper ocean. Haima further deepened the mixed layer and pushed the subsurface warming anomaly caused by Sarika deeper into the ocean and amplified it to $\sim 1.8^{\circ} \mathrm{C}$. In addition, it further increased the upper ocean heat content at Station 2. 3DPWP model simulation shows that the surface cooling was caused by the effects of mixing and horizontal advection, while subsurface warming 
was induced by the combination effects of mixing and downwelling (Sarika) or mainly downwelling (Haima). Downwelling also further warmed the deeper ocean. The maximum sea surface cooling was nearly one day after Sarika, when the combination cooling effects of mixing and horizontal advection were strongest, nearly the half period of the first near-inertial oscillation. The sea surface cooling during Haima seems influenced by the oscillation of surface cooling caused by Sarika. The salinity response to the two typhoons was similar to temperature response, except that the rainfalls during Sarika and Haima successively altered the surface salinity anomaly to $\sim-0.03$ and $\sim-0.1$ psu and also changed the positive subsurface salinity anomaly to negative.

To summarize, Sarika and Haima sequentially induced a near-inertial current and modulated the ocean temperature and salinity structures. Especially, there was some downward push of warm water sequentially into deeper ocean by Sarika and Haima, which may have modulated the ocean interior and deeper ocean. The final oceanic response depends on the relative positions of the successive TCs and the physical processes that they trigger at different locations, for example, the relative importance of mixing, horizontal advection, and vertical advection (upwelling and downwelling) successively caused by the two TCs determines the variations of temperature and salinity profiles. The present work is a case study. A blended data satellite model technique [62] can be used to further study the cases of sequential tropical cyclones. In a word, further study is needed to consider other cases and conduct more in-depth investigations.

Author Contributions: H.Z. formed the ideal and wrote the initial draft; X.L., R.W., X.X., C.Y., D.T. and W.Z. revised the manuscript and provide beneficial suggestions; F.L. visualized Figure 2; L.Y., X.S. (Xiaodong Shang), Y.Q., Y.W., X.S. (Xunshu Song) deployed and recovered the moored observation array, and provide details of the moored data.

Funding: This research was funded by the National Program on Global Change and Air-Sea Interaction (GASI-IPOVAI-04), the China Ocean Mineral Resources Research and Development Association Program (grant number DY135-E2-3-01), the Scientific Research Fund of the Second Institute of Oceanography, MNR (grant number JG1813), the National Natural Science Foundation of China (grant numbers 41806021, 41730535, 41705048, 41621064, 41630970, and 41876022), the Instrument Developing Project of the CAS (grant number YZ201432), and the National Key R\&D Program of China (grant number 2018YFC1506403).

Acknowledgments: We acknowledge the Joint Typhoon Warning Center (JTWC, http://www.usno.navy.mil/JTWC), the Japan Meteorological Agency (JMA, http://www.jma.go.jp/jma/jma-eng/jma-center/rsmc-hp-pub-eg/besttrack. html), and the China Meteorological Administration (CMA, http://tcdata.typhoon.gov.cn) for providing the tropical cyclone tracks, Meteorological Satellite Center of Japan Meteorological Agency and Kochi University (http://weather.is.kochi-u.ac.jp/sat/GAME/2016/Oct/IR1) for providing the cloud-top brightness temperature data of Himawari-8 (https://www.data.jma.go.jp/mscweb/en/index.html), Remote Sensing Systems (http://www.remss. com) for providing the CCMP Version-2.0 vector wind analyses, microwave OI SST data and SMAP salinity data, the National Oceanic and Atmospheric Administration (https://www.cpc.ncep.noaa.gov/products/janowiak/ cmorph_description.html) for providing CMORPH precipitation data, the Copernicus Marine and Environment Monitoring Service (CMEMS, http://www.marine.copernicus.eu) for providing sea surface height anomalies and geostrophic velocity anomalies.

Conflicts of Interest: The authors declare no conflict of interest.

\section{Appendix A. Observation at Mooring 1}

Mooring 1 was deployed at $112^{\circ} 10.699^{\prime} \mathrm{E}$ and $17^{\circ} 59.024^{\prime} \mathrm{N}$ at 16:00 Beijing Time (08:00 UTC) on 6 August and recovered at 19:00 Beijing Time (11:00 UTC) on 27 October. See Figure A1 and Table A1 for the instruments installed at mooring 1 and the physical elements measured. Buoy 1 was deployed at $112^{\circ} 10.699^{\prime} \mathrm{E}$ and $17^{\circ} 59.024^{\prime} \mathrm{N}$ at 10:00 Beijing Time (02:00 UTC) on 6 August, and Buoy 3 was deployed at $114^{\circ} 53.016^{\prime} \mathrm{E}$ and $16^{\circ} 29.000^{\prime} \mathrm{N}$ at 08:30 Beijing Time (00:30 UTC) on 30 July. However, Buoy 1 was damaged after 5 August, and Buoy 3 was damaged after 29 August and 23 September sequentially, so there were no data from the two buoys during Sarika and Haima.

Before the two typhoons, the background upper and bottom ocean currents were south-westward and north-eastward respectively at Station 1 (Figure A2a,b). Near-inertial oscillations occurred after Sarika and Haima at both Stations 1, with the maximum current speed reaching $\sim 80 \mathrm{~cm} / \mathrm{s}$ in the mixed layer. Sarika dramatically intensified the upper ocean current because it was very close to the 
TC track (only $15.77 \mathrm{~km}$ away), and Haima might also have intensified the near-inertial current and caused a slight distortion of the current phase. The results of the spectral analysis in Figure A2a,b reveals significant near-inertial, diurnal, and semidiurnal frequency signals of the current from the ocean surface to the bottom. There was $\sim 10 \%$ blue shift of the near-inertial frequency at Station 1 (Figure A2e-h). This is consistent with Station 1 being close to the TC track (especially that of Sarika) where the near-inertial current was generated. The blue shift of the near-inertial frequency also decreased with increasing depth in the upper ocean at Station 1 , as another consequence of the wave dispersion. It should be noted that there was also a weak super-inertial wave signal with a frequency twice the inertial frequency ( $2 f)$.

At Station 1 (with the operation of Mooring 1, Figure A3), Sarika caused net upwelling and downwelling, which were respectively accompanied by uplifting and depression of the temperature profiles, respectively. Sarika uplifted the $10{ }^{\circ} \mathrm{C}$ isotherm as much as $\sim 50 \mathrm{~m}$ in one day, then the $10{ }^{\circ} \mathrm{C}$ isotherm seems downward pushed back by Haima. The interior ocean exhibited $\sim-0.5^{\circ} \mathrm{C}$ temperature anomaly after Sarika, with Haima, subsequently causing an alteration to a warming anomaly $\left(\sim 0.1^{\circ} \mathrm{C}\right)$. As a result, the average temperature anomaly and heat content were also negative ( $\sim 250 \mathrm{~m}^{\circ} \mathrm{C}$ in maximum) after Sarika and positive after Haima $\left(\sim 200 \mathrm{~m}^{\circ} \mathrm{C}\right.$ in maximum). It indicates that although Station 1 was far away $(\sim 535.57 \mathrm{~km})$ from Haima, its downwelling effect cannot be ignored. However, the temperature anomaly may also have disturbed by the background current and the observation uncertainty. Figure A3a-d indicate that the uplifting effect of Sarika could have reached the bottom of the ocean.

Figure A4 shows the salinity response during Sarika and Haima at Station 2. Because the salinity sensors may have some deviations and inaccuracy, the analysis of salinity response should be careful. Because of the subsurface salinity maximum in Station 2, upwelling (downwelling) caused salinity increase (decrease) upper (lower) than the subsurface maximum. The salinity anomaly between $280 \mathrm{~m}$ and $400 \mathrm{~m}$ was $\sim-0.02 \mathrm{psu}$ after Sarika turned to $\sim 0.01 \mathrm{psu}$ after Haima at Mooring 1 (Figure A4a-c). Because there was a weak updrift of salinity profile during 16 October at Buoy 2 (Figure A4d-f), there was a weak increase of $\sim 0.07 \mathrm{psu}$ in the salinity between $40 \mathrm{~m}$ and $80 \mathrm{~m}$ after Sarika. However, Sarika's rainfall reversed the surface salinity anomaly to $\sim-0.03$ psu. Haima's rainfall further refreshed the mixed layer, reducing the surface salinity anomaly to $\sim-0.1 \mathrm{psu}$; it also changed the positive salinity anomaly between depths of 40 and $80 \mathrm{~m}$ into a negative anomaly. 


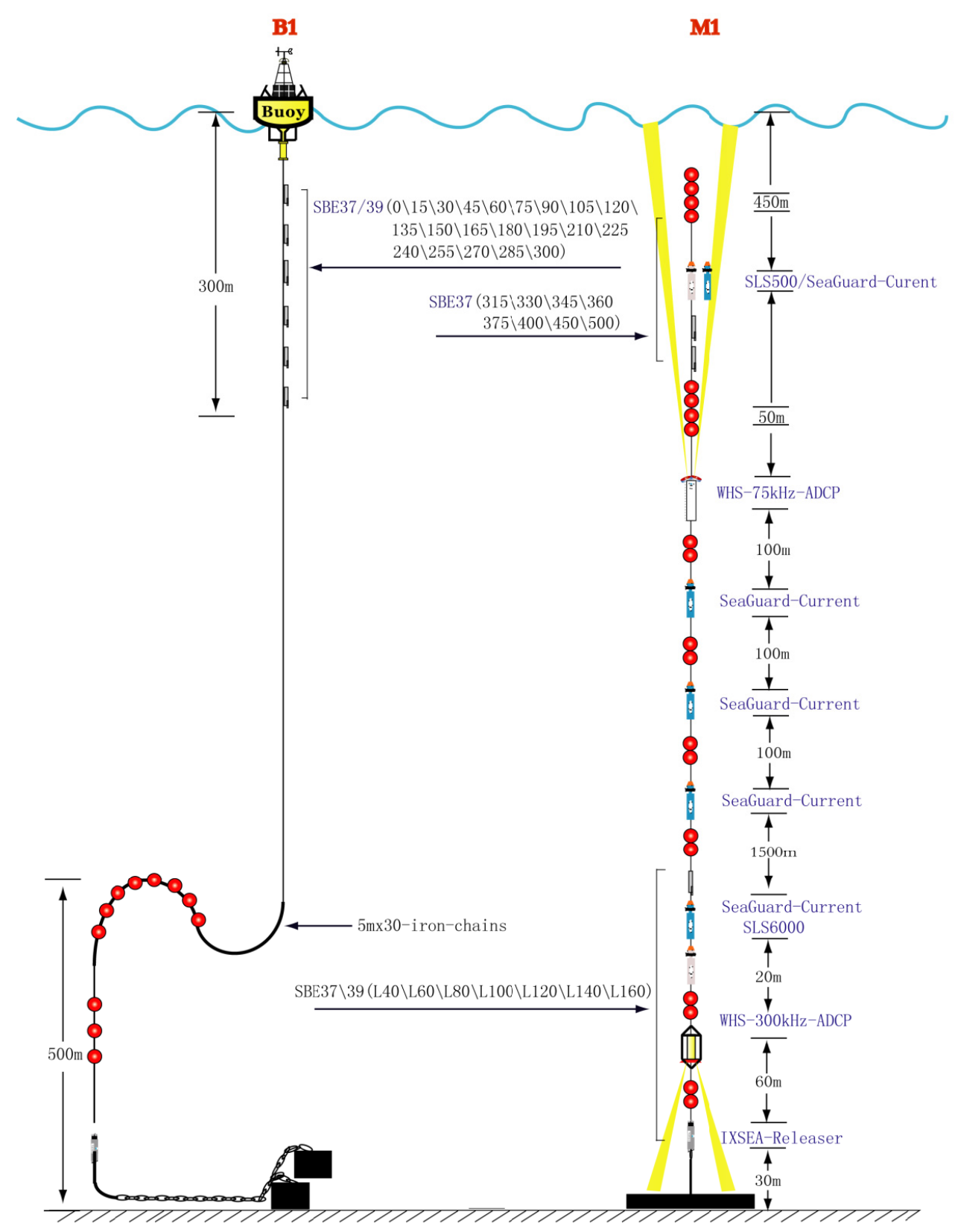

Figure A1. Design of buoy and mooring at Station 1.

Table A1. Observation instruments and measured elements at Mooring 1 *.

\begin{tabular}{cccc}
\hline Instruments & $\begin{array}{c}\text { Observation } \\
\text { Elements }\end{array}$ & Designed Depth (m) & Resolution (s) \\
\hline SBE-37 & $T, S, P$ & $315 / 330 / 345 / 360 / 375 / 400 / 450 / 500 / L 160 / L 140 / L 120 / L 80 / L 40$ & 120 \\
SBE-39 & $T, P$ & L200/L180/L100/L60 & 120 \\
Seaguard & $U, V$ & $450 / 600 / 700 / 800 / L 100$ & 600 \\
RDI 75K-ADCP & $U, V$ & location: 500 m, uplooking; first bin: $24.42 \mathrm{~m}$; last bin: & 600 \\
RDI 75K-ADCP & $U, V$ & location: L80 m, downlooking; first bin: $6.17 \mathrm{~m}$; last & 600 \\
\hline
\end{tabular}

* L: above ocean bottom; for example, L140 means $140 \mathrm{~m}$ above the ocean bottom. $T, S, P, U$, and $V$ respectively denote temperature, salinity, pressure, eastward current speed, and northward current speed, respectively. 

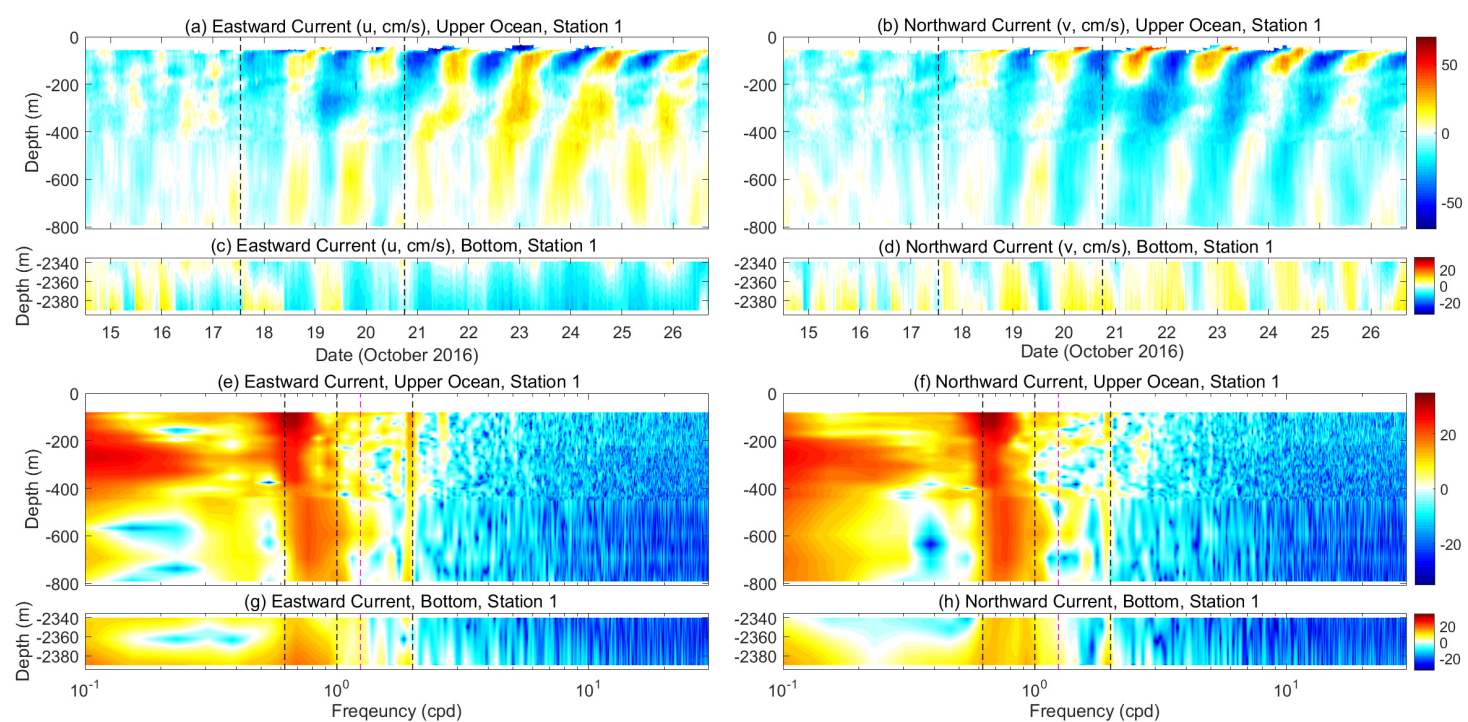

Figure A2. Eastward and northward current (a-d) at Station 1. Spectra of the eastward and northward currents at (e-h) Station 1 between October 13 and 26. The black dashed lines indicate the inertial, diurnal, and semidiurnal frequencies. The violet dashed lines indicate twice the inertial frequency.

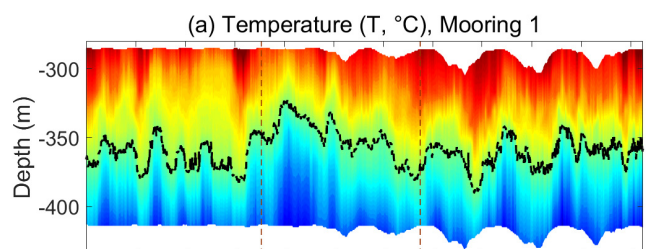

(d) Temperature Anomaly $\left(\Delta \mathrm{T},{ }^{\circ} \mathrm{C}\right)$, Mooring 1

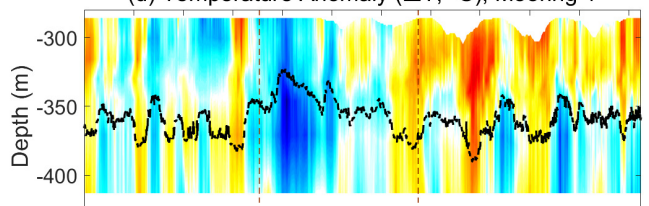

(g) Heat $\left(m^{\circ} \mathrm{C}\right)$, Mooring 1

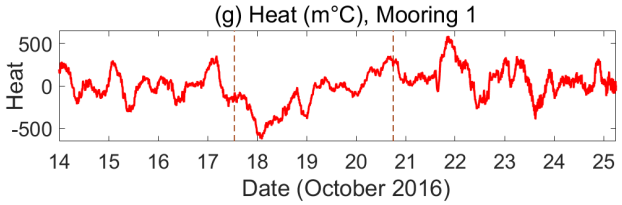

(b) Net Temperature $\left(\mathrm{Tn},{ }^{\circ} \mathrm{C}\right)$, Mooring 1

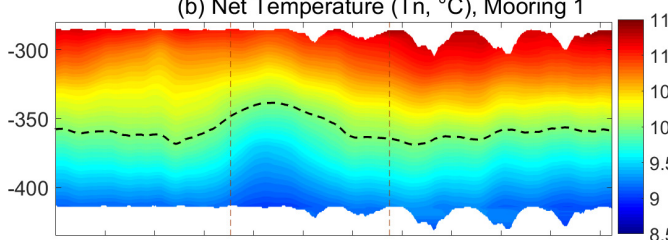

(e) Net Temperature Anomaly $\left(\Delta \mathrm{Tn},{ }^{\circ} \mathrm{C}\right)$, Mooring 1

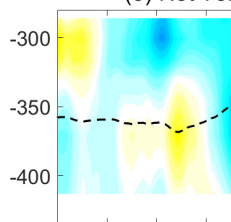

(h) Net Heat $\left(m^{\circ} \mathrm{C}\right)$, Mooring 1

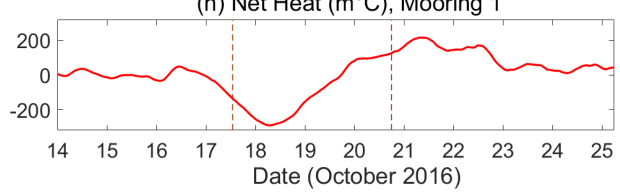

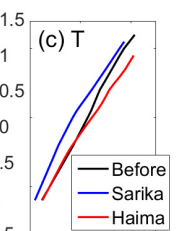

$\begin{array}{lll}9 & 10 & 11\end{array}$

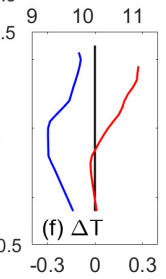

$\left({ }^{\circ} \mathrm{C}\right)$

Figure A3. Variations in the (a) temperature and (b) net temperature at Mooring 1 during Sarika and Haima. The black dashed lines are the $10{ }^{\circ} \mathrm{C}$ isotherms, and the brown lines indicate the times when Sarika and Haima were closest to Mooring 1. (c) Average temperature profiles before the two typhoons (black; averaged between 14 and 16 October), after Sarika (blue; averaged over one inertial period after 18 October), and after Haima (red; averaged over one inertial period after 22 October). (d-f) Temperature anomaly parameters corresponding to the temperature parameters in $(\mathbf{a}-\mathbf{c})$. $(\mathbf{g})$ Heat content anomaly and (h) net heat content anomaly observed between 300 and $410 \mathrm{~m}$ (red lines). The net temperature and net heat content are respectively the moving averages of the temperature and heat content over one inertial period. 



Figure A4. Variations in the salinity and net salinity in the inner $(\mathbf{a}-\mathbf{d})$ and bottom $(\mathbf{e}-\mathbf{h})$ ocean at Mooring 1 during Sarika and Haima.

\section{Appendix B. Bottom Temperature}

Figure A5 shows the bottom temperature observed at Mooring 1 and Mooring 2. There is diurnal and semidiurnal temperature variation. Figure A5a-d indicate that the uplifting effect of Sarika could have reached the bottom of the ocean. There is a bottom temperature signal with the period nearly three days at Mooring 2 (Figure A5e-h).
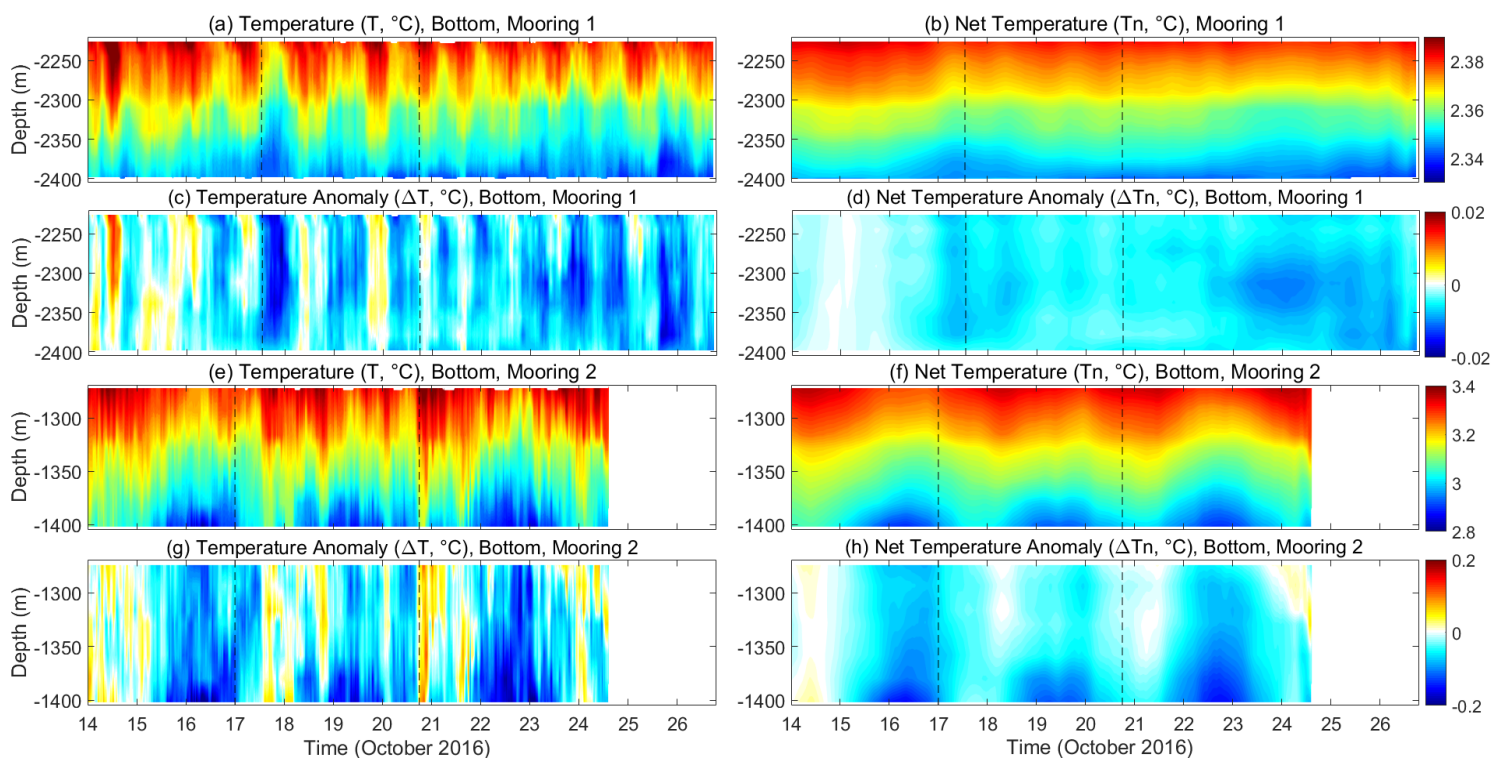

Figure A5. Temperature, net temperature, and their anomaly during Sarika and Haima at the bottom of Mooring 1 (a-d) and Mooring $2(\mathbf{e}-\mathbf{h})$. Net temperature is the one inertial period running mean of temperature response. The temperature anomaly was calculated as the temperature minus the average temperature over the period UTC 00:00 on 13 October to UTC 00:00 on 15 October. Dashed lines represent the time that Sarika and Haima were closest to the stations.

\section{References}

1. Babin, S.M.; Carton, J.A.; Dickey, T.D.; Wiggert, J.D. Satellite evidence of hurricane-induced phytoplankton blooms in an oceanic desert. J. Geophys. Res. 2004, 109, C03043. [CrossRef] 
2. Lin, I.-I.; Wu, C.; Chiang, J.C.H.; Sui, C.; Lin, I.; Liu, W.T. Satellite observations of modulation of surface winds by typhoon-induced upper ocean cooling. Geophys. Res. Lett. 2003, 30, 1131. [CrossRef]

3. Zhao, H.; Pan, J.; Han, G.; Devlin, A.T.; Zhang, S.; Hou, Y. Effect of a fast-moving tropical storm Washi on phytoplankton in the northwestern South China Sea. J. Geophys. Res. Ocean. 2017, 122, 3404-3416. [CrossRef]

4. Ning, J.; Xu, Q.; Zhang, H.; Wang, T.; Fan, K. Impact of Cyclonic Ocean Eddies on Upper Ocean Thermodynamic Response to Typhoon Soudelor. Remote Sens. 2019, 11, 938. [CrossRef]

5. Korty, R.L.; Emanuel, K.A.; Scott, J.R. Tropical Cyclone-Induced Upper-Ocean Mixing and Climate: Application to Equable Climates. J. Clim. 2008, 21, 638-654. [CrossRef]

6. Emanuel, K.A. Contribution of tropical cyclones to meridional heat transport by the oceans. J. Geophys. Res. 2001, 106, 14771-14781. [CrossRef]

7. Sriver, R.L.; Huber, M. Observational evidence for an ocean heat pump induced by tropical cyclones. Nature 2007, 447, 577-580. [CrossRef]

8. Liu, L.L.; Wang, W.; Huang, R.X. The Mechanical Energy Input to the Ocean Induced by Tropical Cyclones. J. Phys. Oceanogr. 2008, 38, 1253-1266. [CrossRef]

9. Knaff, J.A.; DeMaria, M.; Sampson, C.R.; Peak, J.E.; Cummings, J.; Schubert, W.H. Upper Oceanic Energy Response to Tropical Cyclone Passage. J. Clim. 2013, 26, 2631-2650. [CrossRef]

10. Nilsson, J. Energy Flux from Traveling Hurricanes to the Oceanic Internal Wave Field. J. Phys. Oceanogr. 1995, 25, 558-573. [CrossRef]

11. Schade, L.R.; Emanuel, K.A. The Ocean's Effect on the Intensity of Tropical Cyclones: Results from a Simple Coupled Atmosphere-Ocean Model. J. Atmos. Sci. 1999, 56, 642-651. [CrossRef]

12. Emanuel, K.; Desautels, C.; Holloway, C.; Korty, R. Environmental Control of Tropical Cyclone Intensity. J. Atmos. Sci. 2004, 61, 843-858. [CrossRef]

13. Emanuel, K.A. An Air-Sea Interaction Theory for Tropical Cyclones. Part I: Steady-State Maintenance. J. Atmos. Sci. 1986, 43, 585-605. [CrossRef]

14. Emanuel, K.A. Thermodynamic control of hurricane intensity. Nature 1999, 401, 665-669. [CrossRef]

15. Zhang, H.; Chen, D.; Zhou, L.; Liu, X.; Ding, T.; Zhou, B. Upper ocean response to Typhoon Kalmaegi (2014). J. Geophys. Res. Ocean. 2016, 121, 6520-6535. [CrossRef]

16. Guan, S.; Zhao, W.; Huthnance, J.; Tian, J.; Wang, J. Observed upper ocean response to typhoon Megi (2010) in the Northern South China Sea. J. Geophys. Res. Ocean. 2014, 119, 3134-3157. [CrossRef]

17. Xu, J.; Huang, Y.; Chen, Z.; Liu, J.; Liu, T.; Li, J.; Cai, S.; Ning, D. Horizontal variations of typhoon-forced near-inertial oscillations in the south China sea simulated by a numerical model. Cont. Shelf Res. 2019, 180, 24-34. [CrossRef]

18. Ma, Y.; Zhang, S.; Qi, Y.; Jing, Z. Upper ocean near-inertial response to the passage of two sequential typhoons in the northwestern South China Sea. Sci. China Earth Sci. 2019, 62, 863-871. [CrossRef]

19. Mitarai, S.; McWilliams, J.C. Wave glider observations of surface winds and currents in the core of Typhoon Danas. Geophys. Res. Lett. 2016, 43, 11312-11319. [CrossRef]

20. D'Asaro, E.A. The Energy Flux from the Wind to Near-Inertial Motions in the Surface Mixed Layer. J. Phys. Oceanogr. 1985, 15, 1043-1059. [CrossRef]

21. Alford, M.H.; MacKinnon, J.A.; Simmons, H.L.; Nash, J.D. Near-Inertial Internal Gravity Waves in the Ocean. Annu. Rev. Mar. Sci. 2016, 8, 95-123. [CrossRef] [PubMed]

22. Zhang, H.; Wu, R.; Chen, D.; Liu, X.; He, H.; Tang, Y.; Ke, D.; Shen, Z.; Li, J.; Xie, J.; et al. Net modulation of upper ocean thermal structure by Typhoon Kalmaegi. J. Geophys. Res. Ocean. 2018, 123, 7154-7171. [CrossRef]

23. Greatbatch, R.J. On the Response of the Ocean to a Moving Storm: Parameters and Scales. J. Phys. Oceanogr. 1984, 14, 59-78. [CrossRef]

24. Greatbatch, R.J. On the Response of the Ocean to a Moving Storm: The Nonlinear Dynamics. J. Phys. Oceanogr. 1983, 13, 357-367. [CrossRef]

25. Gill, A.E. On the Behavior of Internal Waves in the Wakes of Storms. J. Phys. Oceanogr. 1984, 14, 1129-1151. [CrossRef]

26. Kunze, E. Near-Inertial Wave Propagation in Geostrophic Shear. J. Phys. Oceanogr. 1985, 15, 544-565. [CrossRef]

27. Hibiya, T.; Niwa, Y. Nonlinear processes of energy transfer from traveling hurricanes to the deep ocean internal wave field. J. Geophys. Res. Space Phys. 1997, 102, 12469-12477. 
28. Meroni, A.N.; Miller, M.D.; Tziperman, E.; Pasquero, C. Nonlinear Energy Transfer among Ocean Internal Waves in the Wake of a Moving Cyclone. J. Phys. Oceanogr. 2017, 47, 1961-1980. [CrossRef]

29. Price, J.F. Upper Ocean Response to a Hurricane. J. Phys. Oceanogr. 1981, 11, 153-175. [CrossRef]

30. Samson, G.; Giordani, H.; Caniaux, G.; Roux, F. Numerical investigation of an oceanic resonant regime induced by hurricane winds. Ocean Dyn. 2009, 59, 565-586. [CrossRef]

31. Yang, Y.J.; Chang, M.H.; Hsieh, C.Y.; Chang, H.I.; Jan, S.; Wei, C.L. The role of enhanced velocity shears in rapid ocean cooling during Super Typhoon Nepartak 2016. Nat. Commun. 2019, 10, 1627. [CrossRef] [PubMed]

32. Black, W.J.; Dickey, T.D. Observations and analyses of upper ocean responses to tropical storms and hurricanes in the vicinity of Bermuda. J. Geophys. Res. 2008, 113, C08009. [CrossRef]

33. Yue, X.; Zhang, B.; Liu, G.; Li, X.; Zhang, H.; He, Y. Upper Ocean Response to Typhoon Kalmaegi and Sarika in the South China Sea from Multiple-Satellite Observations and Numerical Simulations. Remote Sens. 2018, 10, 348. [CrossRef]

34. Cheung, H.-F.; Pan, J.; Gu, Y.; Wang, Z. Remote-sensing observation of ocean responses to Typhoon Lupit in the northwest Pacific. Int. J. Remote Sens. 2012, 34, 1478-1491. [CrossRef]

35. Price, J.F.; Morzel, J.; Niiler, P.P. Warming of SST in the cool wake of a moving hurricane. J. Geophys. Res. 2008, 113, C07010. [CrossRef]

36. Chiang, T.L.; Wu, C.R.; Oey, L.Y. Typhoon Kai-Tak: An Ocean's Perfect Storm. J. Phys. Oceanogr. 2011, 41, 221-233. [CrossRef]

37. Glenn, S.M.; Miles, T.N.; Seroka, G.N.; Xu, Y.; Forney, R.K.; Yu, F.; Roarty, H.; Schofield, O.; Kohut, J. Stratified coastal ocean interactions with tropical cyclones. Nat. Commun. 2016, 7, 10887. [CrossRef] [PubMed]

38. Wu, R.; Zhang, H.; Chen, D.; Li, C.; Lin, J. Impact of Typhoon Kalmaegi on the South China Sea: Simulations using a fully coupled atmosphere-ocean-wave model. Ocean Model. 2018, 131, 132-151. [CrossRef]

39. Lin, S.; Zhang, W.-Z.; Shang, S.-P.; Hong, H.-S. Ocean response to typhoons in the western North Pacific: Composite results from Argo data. Deep. Sea Res. Part I Oceanogr. Res. Pap. 2017, 123, 62-74. [CrossRef]

40. Cheng, L.; Zhu, J.; Sriver, R.L. Global representation of tropical cyclone-induced short-term ocean thermal changes using Argo data. Ocean Sci. 2015, 11, 719-741. [CrossRef]

41. Liu, Z.; Xu, J.; Sun, C.; Wu, X. An upper ocean response to Typhoon Bolaven analyzed with Argo profiling floats. Acta Oceanol. Sin. 2014, 33, 90-101. [CrossRef]

42. Hsu, P.C.; Ho, C.R. Typhoon-induced ocean subsurface variations from glider data in the Kuroshio region adjacent to Taiwan. J. Oceanogr. 2018, 75, 1-21. [CrossRef]

43. GirishKumar, M.S.; Suprit, K.; Chiranjivi, J.; Bhaskar, T.V.S.U.; Ravichandran, M.; Shesu, R.V.; Rao, E.P.R. Observed oceanic response to tropical cyclone Jal from a moored buoy in the south-western Bay of Bengal. Ocean Dyn. 2014, 64, 325-335. [CrossRef]

44. McPhaden, M.J.; Foltz, G.R.; Lee, T.; Murty, V.S.N.; Ravichandran, M.; Vecchi, G.A.; Vialard, J.; Wiggert, J.D.; $\mathrm{Yu}, \mathrm{L}$. Ocean-Atmosphere Interactions during Cyclone Nargis. Eos 2009, 90, 53-54. [CrossRef]

45. Maneesha, K.; Murty, V.; Ravichandran, M.; Lee, T.; Yu, W.; McPhaden, M. Upper ocean variability in the Bay of Bengal during the tropical cyclones Nargis and Laila. Prog. Oceanogr. 2012, 106, 49-61. [CrossRef]

46. Baranowski, D.B.; Flatau, P.J.; Chen, S.; Black, P.G. Upper ocean response to the passage of two sequential typhoons. Ocean Sci. 2014, 10, 559-570. [CrossRef]

47. Wu, R.; Li, C. Upper ocean response to the passage of two sequential typhoons. Deep. Sea Res. Part I: Oceanogr. Res. Pap. 2018, 132, 68-79. [CrossRef]

48. Balaguru, K.; Taraphdar, S.; Leung, L.R.; Foltz, G.R.; Knaff, J.A. Cyclone-cyclone interactions through the ocean pathway. Geophys. Res. Lett. 2014, 41, 6855-6862. [CrossRef]

49. Atlas, R.; Hoffman, R.N.; Ardizzone, J.; Leidner, S.M.; Jusem, J.C.; Smith, D.K.; Gombos, D. A Cross-calibrated, Multiplatform Ocean Surface Wind Velocity Product for Meteorological and Oceanographic Applications. Bull. Am. Meteorol. Soc. 2011, 92, 157-174. [CrossRef]

50. Joyce, R.J.; Janowiak, J.E.; Arkin, P.A.; Xie,P.CMORPH: A Method that Produces Global Precipitation Estimates from Passive Microwave and Infrared Data at High Spatial and Temporal Resolution. J. Hydrometeorol. 2004, 5, 487-503. [CrossRef]

51. Gentemann, C.L.; Meissner, T.; Wentz, F.J. Accuracy of satellite sea surface temperatures at 7 and $11 \mathrm{GHz}$. IEEE Trans. Geosci. Remote Sens. 2010, 48, 1009-1018. [CrossRef] 
52. Meissner, T.; Wentz, F.J.; Le Vine, D.M. The Salinity Retrieval Algorithms for the NASA Aquarius Version 5 and SMAP Version 3 Releases. Remote Sens. 2018, 10, 1121. [CrossRef]

53. Ying, M.; Zhang, W.; Yu, H.; Lu, X.; Feng, J.; Fan, Y.; Zhu, Y.; Chen, D. An Overview of the China Meteorological Administration Tropical Cyclone Database. J. Atmos. Ocean. Technol. 2014, 31, 287-301. [CrossRef]

54. Price, J.F.; Sanford, T.B.; Forristall, G.Z. Forced Stage Response to a Moving Hurricane. J. Phys. Oceanogr. 1994, 24, 233-260. [CrossRef]

55. Price, J.F.; Weller, R.A.; Pinkel, R. Diurnal cycling: Observations and models of the upper ocean response to diurnal heating, cooling, and wind mixing. J. Geophys. Res. 1986, 91, 8411-8427. [CrossRef]

56. Pun, I.F.; Lin, I.I.; Lien, C.C.; Wu, C.C. Influence of the size of Supertyphoon Megi (2010) on SST cooling. Mon. Weather Rev. 2018, 146, 661-677. [CrossRef]

57. Sanford, T.B.; Price, J.F.; Girton, J.B.; Webb, D.C. Highly resolved observations and simulations of the ocean response to a hurricane. Geophys. Res. Lett. 2007, 34. [CrossRef]

58. Sanford, T.B.; Price, J.F.; Girton, J.B. Upper-Ocean Response to Hurricane Frances (2004) Observed by Profiling EM-APEX Floats. J. Phys. Oceanogr. 2011, 41, 1041-1056. [CrossRef]

59. Xie, X.H.; Shang, X.D.; Chen, G.Y.; Zhang, Y.Z.; Xie, X.; Shang, X.; Van Haren, H.; Chen, G.; Zhang, Y. Observations of parametric subharmonic instability-induced near-inertial waves equatorward of the critical diurnal latitude. Geophys. Res. Lett. 2011, 38, L05603. [CrossRef]

60. Yan, Y.; Li, L.; Wang, C. The effects of oceanic barrier layer on the upper ocean response to tropical cyclones. J. Geophys. Res. Ocean. 2017, 122, 4829-4844. [CrossRef]

61. Balaguru, K.; Chang, P.; Saravanan, R.; Leung, L.R.; Xu, Z.; Li, M.; Hsieh, J.-S. Ocean barrier layers' effect on tropical cyclone intensification. Proc. Natl. Acad. Sci. USA 2012, 109, 14343-14347. [CrossRef] [PubMed]

62. Montuori, A.; Ricchi, A.; Benassai, G.; Migliaccio, M. Sea Wave Numerical Simulation and Verification in Tyrrhenian Costal Area with X-Band Cosmo-Skymed Sar Data. In Proceedings of the ESA, SOLAS \& EGU Joint Conference 'Earth Observation for Ocean-Atmosphere Interactions Science', Frascati, Italy, 29 November-2 December 2011. 